\title{
Gross chemical composition, fatty acids, sterols, and pigments in tropical seaweed species off Sinaloa, Mexico
}

\section{Composición proximal, ácidos grasos, esteroles y pigmentos en especies tropicales de algas marinas frente a Sinaloa, México}

\author{
Idalia Osuna-Ruiz ${ }^{1,2}$, Mario Nieves-Soto ${ }^{1}$, Mercedes Marlenne Manzano-Sarabia ${ }^{1}$, Enrique Hernández-Garibay ${ }^{3,4}$, \\ Jaime Lizardi-Mendoza ${ }^{5}$, Armando Burgos-Hernández ${ }^{6}$, Miguel Ángel Hurtado-Oliva ${ }^{1 *}$ \\ ${ }^{1}$ Facultad de Ciencias del Mar, Universidad Autónoma de Sinaloa, Paseo Claussen, s/n, CP 82000, Mazatlán, Sinaloa, \\ Mexico. \\ 2 Unidad Académica de Ingeniería en Biotecnología, Universidad Politécnica de Sinaloa, Carretera municipal libre \\ Mazatlán-Higueras, km 3, CP 82199, Mazatlán, Sinaloa, Mexico. \\ 3 Facultad de Ciencias Marinas, Universidad Autónoma de Baja California, Carretera Transpeninsular Ensenada-Tijuana, \\ no. 3917, CP 22860, Ensenada, Baja California, Mexico. \\ 4 Centro Regional de Investigación Acuícola y Pesquera de Ensenada, Instituto Nacional de Pesca, Carretera Tijuana- \\ Ensenada, km 97.5, CP 22800, Ensenada, Baja California, Mexico. \\ 5 Centro de Investigaciones en Alimentos y Desarrollo, Carretera a la Victoria, km 0.6, CP 83304, Hermosillo, Sonora, \\ Mexico. \\ 6 Departamento de Investigación y Posgrado en Alimentos, Universidad de Sonora, Blvd. Luis Encinas y Rosales, s/n, Col. \\ Centro, CP 83000, Hermosillo, Sonora, Mexico.
}

* Corresponding author. E-mail: mholiva@uas.edu.mx

\begin{abstract}
Biochemical composition was assessed in green (Ulva expansa, Caulerpa sertularioides, Rhizoclonium riparium, Codium isabelae), red (Spyridia filamentosa, Gracilaria vermiculophylla), and brown (Padina durvillaei) seaweeds collected from different tropical lagoons on the Pacific coast of Sinaloa, Mexico. Protein content was higher in C. sertularioides, S. filamentosa, and G. vermiculophylla (10-12\%), followed by $R$. riparium, P. durvillaei, and $U$. expansa ( $8 \%, 6 \%$, and $4 \%$, respectively). Lipid content was in the range of $0.3-1.5 \%$, with the highest value found in $R$. riparium. The highest content of nitrogen-free extract (i.e., carbohydrates) (69\%) and the lowest ash value (25\%) were assessed in P. durvillaei. Polyunsaturated fatty acid content was in the range of 5-45\%, with higher values in $R$. riparium (45\%), C. sertularioides (39\%), and P. durvillaei (23\%). Red seaweeds showed the highest value of cholesterol+dehydrocholesterol ( $>90 \%)$, while green seaweeds showed the highest contents of $\beta$-sitosterol (71-77\%), except for U. expansa, for which fucosterol+isofucosterol (79\%) was highest. Pigment composition was different among seaweeds but coincided with previous reports. The biochemical components used as biomarkers were assessed by principal component analysis to discriminate among assessed variables and to cluster seaweed species according to the common variability of their biochemical composition. Results showed that composition was similar within seaweed divisions but particularly different in U. expansa and P. durvillaei. Biochemical compounds that contributed to total variability were $\beta$-sitosterol, 20:4n-6, 20:5n-3, chlorophyll $a$ and $b$, and $\beta$-carotene, and to a lesser extent fucosterol+isofocusterol and 22:6n-3. Results showed that the analyzed seaweed species may be useful for animal nutrition and appropriate for human consumption.
\end{abstract}

Keywords: sterols, lipids, pigments, biochemical compostition, chemopreventive compounds.

RESUMEN. Se determinó la composición bioquímica de algas verdes (Ulva expansa, Caulerpa sertularioides, Rhizoclonium riparium, Codium isabelae), rojas (Spyridia filamentosa, Gracilaria vermiculophylla) y parda (Padina durvillaei) recolectadas en diferentes lagunas tropicales en la costa del Pacífico en Sinaloa, México. El contenido de proteínas fue más alto en C. sertularioides, S. filamentosa y G. vermiculophylla (10-12\%), seguido de R. riparium, P. durvillaei y U. expansa ( $8 \%, 6 \%$ y 4\%, respectivamente). El contenido de lípidos se encontró en el intervalo de $0.3-1.5 \%$, con el valor más alto encontrado en $R$. riparium. El contenido más alto del extracto libre de nitrógeno (i.e., carbohidratos) (69\%) y el valor más bajo de cenizas (25\%) se encontró en $P$. durvillaei. El contenido de ácidos grasos poliinsaturados (AGPI) se encontró en el intervalo del 5\% al 45\%, con los valores más altos en $R$. riparium (45\%), C. sertularioides (39\%) y P. durvillaei (23\%). Las algas rojas mostraron el mayor valor de colesterol+dehidrocolesterol (>90\%), mientras que las algas verdes mostraron el mayor contenido de $\beta$-sitosterol (71-77\%), excepto U. expansa, para la cual el principal esterol fue el fucoesterol+isofucosterol (79\%). El contenido de pigmentos fue diferente entre las algas, aunque coincidió con reportes previos. Los componentes bioquímicos usados como biomarcadores se analizaron por componentes principales para discriminar entre las variables analizadas y agrupar las especies de algas en función de la variabilidad de su composición bioquímica. Los resultados mostraron una composición similar en cada grupo de algas, pero particularmente diferente en $U$. expansa y P. durvillaei. Los compuestos bioquímicos que contribuyeron a la variabilidad total fueron $\beta$-sitosterol, 20:4n-6, 20:5n-3, clorofila $a$ y $b$, $\beta$-caroteno y, en menor grado, fucosterol+isofucosterol y 22:6n-3. Los resultados indican que las especies de algas analizadas podrían ser utilizadas como alimento para animales, pero también para consumo humano.

Palabras clave: esteroles, lípidos, pigmentos, composición bioquímica, compuestos quimiopreventivos. 


\section{INTRODUCTION}

Seaweeds are primary producers in all oceans and they release significant quantities of oxygen to the atmosphere (Mann 1973). Seaweeds are also an important food source, and they are usually used as nursery and shelter habitats by an important number of aquatic organisms (Lobban and Harrison 1994, Christie et al. 2009). As food sources, seaweeds contain a variety of nutritive and bioactive compounds (Plaza et al. 2008, 2010), such as proteins, carbohydrates, different kinds of lipids like essential fatty acids (i.e., arachidonic acid, eicosapentaenoic acid, and docosahexaenoic acid) and sterols (i.e., cholesterol), and pigments (i.e., chlorophylls and carotenoids). All of these nutritionally important biochemical components are transferred to upper levels in the marine food web (Guschina and Harwood 2006).

Seaweeds are distributed throughout different biogeographic regions according to climate. At least 2 regions with temperate and tropical conditions have been demonstrated to explain the distribution and abundance of seaweeds on the Pacific Coast of Mexico (van den Hoek 1984, Silva 1992, Paul-Chávez and Riosmena-Rodriguez 2000, Garbary 2001). Geographic distribution is usually explained by climate variations, whereby high-latitude environments (cold or temperate) have greater annual variations in climatic conditions than low-latitude environments (tropical), favoring more tolerant species with a broad geographic distribution. Thus, organisms inhabiting high-latitude environments are expected to have broader climatic tolerance compared with organisms inhabiting low-latitude environments (Stevens 1989, 1992). Differences in seaweed growth rates and biochemical composition as a response to adaptation to environmental conditions should therefore be expected. Additionally, seasonal, interannual, and species-specific variations have been associated with the biochemical composition of different seaweeds, and this association has been explained by changes in environmental parameters such as temperature, salinity, solar radiation, and nutrient availability (Xu et al. 1998, Nelson et al. 2002, Guschina and Harwood 2006, Hurtado et al. 2011, Polat and Ozogul 2013).

In Mexico, the chemoprotectant properties in seaweed biochemical composition and the nutritional value of seaweeds have been evaluated in some species from the Gulf of Mexico and the Caribbean Sea (Robledo and Freile Pelegrín 1997, Aguilera-Morales et al. 2005, Peña-Rodríguez et al. 2011). The interannual and seasonal variations in fatty acids (Nelson et al. 2002, Serviere-Zaragoza et al. 2015) and proximate composition (Serviere-Zaragoza et al. 2002) have been described for some seaweed species in temperate seawaters of the northeastern Pacific Ocean. Only 2 studies have been performed on tropical seaweed species off the Pacific coast of Mexico. In one of them, the effect of season (summer vs winter) on the proximal composition and fatty acid and

\section{INTRODUCCIÓN}

Las algas marinas son productores primarios que están presentes en todos los océanos y liberan importantes cantidades de oxígeno a la atmósfera (Mann 1973). Son, además, una importante fuente de alimento $\mathrm{y}$, frecuentemente, son utilizadas como nichos de crianza y escondite por un importante número de organismos acuáticos (Lobban y Harrison 1994, Christie et al. 2009). Como fuente de alimento, las algas marinas contienen una amplia variedad de compuestos nutritivos y bioactivos (Plaza et al. 2008, Plaza et al. 2010), tales como proteínas, carbohidratos, diferentes tipos de lípidos como ácidos grasos esenciales (i.e., ácido araquidónico, ácido eicosapentaenoico y ácido docosahexaenoico) y esteroles (i.e., colesterol), y pigmentos (i.e., clorofila y carotenoides). Todos estos compuestos bioquímicos de importancia nutricional son transferidos a los niveles superiores de la cadena trófica en el mar (Guschina y Harwood 2006).

Las algas marinas se distribuyen en diferentes regiones biogeográficas de acuerdo con las condiciones climáticas. Para explicar la distribución y la abundancia de las algas marinas en la costa mexicana del Pacífico, se han identificado al menos 2 regiones de condiciones templadas y tropicales (van den Hoek 1984, Silva 1992, Paul-Chávez y Riosmena-Rodríguez 2000, Garbary 2001). La distribución geográfica generalmente se explica en función de las variaciones climáticas; es decir, los ambientes de latitudes altas (frías o templadas) presentan mayor variación anual en las condiciones climáticas que los ambientes de latitudes bajas (tropicales), lo cual favorece a especies más tolerantes con una amplia distribución geográfica. Por lo tanto, es de esperar que los organismos que habiten en ambientes de latitudes altas se caractericen por una amplia tolerancia a las variaciones climáticas en comparación con los organismos que habiten en ambientes de latitudes bajas (Stevens 1989, 1992). En consecuencia, es de esperar encontrar diferencias en la tasa de crecimiento y la composición bioquímica de algas marinas como respuesta a la adaptación a diferentes condiciones ambientales. Además, las variaciones estacionales, interanuales y especie-específicas están relacionadas con la composición bioquímica de diferentes especies de algas marinas, y esta relación se explica por los cambios en parámetros ambientales como temperatura, salinidad, radiación solar y disponibilidad de nutrientes (Xu et al. 1998, Nelson et al. 2002, Guschina y Harwood 2006, Hurtado et al. 2011, Polat y Ozogul 2013).

En México, se han evaluado la composición bioquímica como fuente de compuestos quimio-protectores y el valor nutricional de algunas especies de algas marinas del golfo de México y el mar Caribe (Robledo y Freile Pelegrín 1997, Aguilera-Morales et al. 2005, Peña-Rodríguez et al. 2011). Las variaciones interanuales y estacionales de la composición de ácidos grasos (Nelson et al. 2002, Serviere-Zaragoza et al. 2015) y la composición proximal (Serviere-Zaragoza et al. 
amino acid contents in 5 tropical seaweeds was evaluated (Peraza-Yee 2014). More recently, the chemopreventive activities assessed in the same species evaluated in this work were demonstrated by the content of flavonoids and chlorophylls (Osuna-Ruiz et al. 2016); however, specific lipids (i.e., polyunsaturated fatty acids and phytosterols) and pigments (i.e., lutein, $\beta$-carotene, and fucoxanthin), which could also be a source of important biochemical components with high nutritional value and with chemopreventive activity, were not analyzed. This highlighted the lack of knowledge on the biochemical composition of seaweed species distributed in the tropical region off the Pacific coast of Mexico. Therefore, the aim of the present study was to assess the proximate fatty acid, sterol, and pigment composition of 7 tropical seaweed species collected from different tropical lagoons on the Pacific coast of Sinaloa, Mexico: 1 Phaephyta, Padina durvillaei Bory Saint-Vincent (Dictyotaceae); 2 Rodhophyta, Spyridia filamentosa (Wulfen) Harvey (Spyridiaceae) and Gracilaria vermiculophylla (Ohmi) Papenfuss (Gracilariaceae); and 4 Chlorophyta, Ulva expansa (Setchell) Setchell \& N.L. Gardner (Ulvaceae), Codium isabelae W.R. Taylor (Codiaceae), Rhizoclonium riparium (Roth) Harvey (Cladophoraceae), and Caulerpa sertularioides (S. G. Gmelin) M. A. Howe (Caulerpaceae).

\section{Materials AND Methods}

\section{Sampling}

Seaweeds were selected according to their seasonal appearance at each location, when abundance was highest, facilitating their sampling. All seaweed species were sampled at the same depth ( 3 to $5 \mathrm{~m}$ ) in the rocky intertidal zone. Approximately $2.5 \mathrm{~kg}$ (about 20 to 30 specimens) of each seaweed species were hand collected in different lagoons along the coast of Sinaloa, Mexico. Rhizoclonium riparium specimens were collected in June 2013 in Urias Lagoon $\left(23^{\circ} 19^{\prime} 0.96^{\prime \prime} \mathrm{N}\right.$, $\left.106^{\circ} 18^{\prime} 46.5^{\prime \prime} \mathrm{W}\right) ;$ S. filamentosa and C. sertularioides were collected in October 2013 in Agiabampo-Bacorehuis Lagoon $\left(26^{\circ} 20^{\prime} 37.2^{\prime \prime} \mathrm{N}, 109^{\circ} 14^{\prime} 34.6^{\prime \prime} \mathrm{W}\right.$ and $26^{\circ} 20^{\prime} 26^{\prime \prime} \mathrm{N}$, $109^{\circ} 12^{\prime} 50^{\prime \prime} \mathrm{W}$, respectively); Gracilaria vermiculophylla was collected in October 2013 in Santa Maria-La Reforma Lagoon $\left(29^{\circ} 50^{\prime} 14.7^{\prime \prime} \mathrm{N}, 108^{\circ} 05^{\prime} 24^{\prime \prime} \mathrm{W}\right)$; and C. isabelae, P. durvillaei, and U. expansa were collected in May 2014 in Mazatlan Bay $\left(23^{\circ} 1{ }^{\prime} 29.1^{\prime \prime} \mathrm{N}, 106^{\circ} 25^{\prime} 29.7^{\prime \prime} \mathrm{W}\right)$. All seaweed specimens were cleaned in situ with seawater (epibionts and necrotic parts were removed) and then transported to the laboratory in plastic bags covered with ice. All weighed fresh seaweed biomass was rinsed with distilled water, lyophilized (FreeZone Plus 4.5 Labconco; Kansas City, MO, USA), and grounded $(0.6 \mathrm{~mm})$ with a commercial grinder. Dried pooled samples were stored at $-70^{\circ} \mathrm{C}$ for proximate composition, while fresh pooled subsamples were used for lipid and pigment analyses.
2002) se han descrito para algunas especies de algas marinas de zonas templadas del noroeste del océano Pacífico. Solo existen 2 trabajos sobre algas marinas tropicales en la costa mexicana del Pacífico. Uno de estos trabajos evaluó el efecto estacional (verano vs invierno) en la composición proximal y el contenido de ácidos grasos y aminoácidos en 5 especies de algas marinas tropicales (Peraza-Yee 2014). Recientemente, se determinó que la actividad quimiopreventiva en las mismas especies de algas marinas evaluadas en este trabajo se debe al contenido de flavonoides y clorofilas (Osuna-Ruiz et al. 2016); sin embargo, no se analizó el contenido de lípidos específicos (i.e., acídos grasos poliinsaturados y fitoesteroles) y pigmentos (i.e., luteína, $\beta$-caroteno y fucoxantina), los cuales pueden ser una fuente importante de compuestos bioquímicos con alto valor nutricional y actividad quimiopreventiva. Esto evidencia una falta de conocimiento sobre la composición bioquímica de las especies de algas marinas que se distribuyen en la región tropical de la costa mexicana del Pacífico. Por lo tanto, el objetivo del presente trabajo fue determinar la composición proximal y el contenido de ácidos grasos, esteroles y pigmentos en 7 especies de algas marinas tropicales recolectadas de diferentes lagunas en la costa del Pacífico de Sinaloa, México: 1 feofita, Padina durvillaei Bory Saint-Vincent (Dictyotaceae); 2 rodofitas, Spyridia filamentosa (Wulfen) Harvey (Spyridiaceae) y Gracilaria vermiculophylla (Ohmi) Papenfuss (Gracilariaceae); y 4 clorofitas, Ulva expansa (Setchell) Setchell \& N.L. Gardner (Ulvaceae), Codium isabelae W.R. Taylor (Codiaceae), Rhizoclonium riparium (Roth) Harvey (Cladophoraceae) y Caulerpa sertularioides (SG Gmelin) M. A. Howe (Caulerpaceae).

\section{MATERIALES Y MÉTOdos}

\section{Muestreo}

Las algas marinas fueron seleccionadas de acuerdo con su aparición estacional, cuando presentaron mayor abundancia en cada sitio, lo cual facilitó su muestreo. Todas las especies de algas marinas fueron recolectadas a la misma profundidad ( 3 a $5 \mathrm{~m}$ ) en la zona intermareal rocosa. Manualmente, se recolectaron aproximadamente $2.5 \mathrm{~kg}$ (alrededor de 20 a 30 especímenes) de cada especie de alga marina en diferentes lagunas a lo largo de la costa de Sinaloa, México. Rhizoclonium riparium fue recolectada en junio de 2013 en la laguna de Urías $\left(23^{\circ} 19^{\prime} 0.96^{\prime \prime} \mathrm{N}, 106^{\circ} 18^{\prime} 46.5^{\prime \prime} \mathrm{W}\right)$; $S$. filamentosa y $C$. sertularioides fueron recolectadas en octubre de 2013 en la laguna de Agiabampo-Bacorehuis $\left(26^{\circ} 20^{\prime} 37.2^{\prime \prime} \mathrm{N}, 109^{\circ} 14^{\prime} 34.6^{\prime \prime} \mathrm{W}\right.$ y $26^{\circ} 20^{\prime} 26^{\prime \prime} \mathrm{N}, 109^{\circ} 12^{\prime} 50^{\prime \prime} \mathrm{W}$, respectivamente); G. vermiculophylla fue recolectada en octubre de 2013 en la laguna de Santa María-La Reforma $\left(29^{\circ} 50^{\prime} 14.7^{\prime \prime} \mathrm{N}, 108^{\circ} 05^{\prime} 24^{\prime \prime} \mathrm{W}\right)$; y C. isabelae, P. durvillaei y $U$. expansa fueron recolectadas en mayo de 2014 en la bahía de Mazatlán $\left(23^{\circ} 1^{\prime} 29.1^{\prime \prime N}, 106^{\circ} 25^{\prime} 29.7^{\prime \prime} \mathrm{W}\right)$. Todos los especímenes de las algas marinas fueron limpiados in situ 


\section{Proximate composition analyses}

Moisture, ash content, crude protein, and ether-soluble matter (lipids) were assessed in all seaweed species according to AOAC (2006). Moisture content (\%) was determined by drying $2 \mathrm{~g}$ of wet samples in an oven dryer (Lindberg/blue, Thermo Scientific; Waltham, MA, USA) at $105{ }^{\circ} \mathrm{C}$ until reaching constant weight. Ash content was determined by calcination of samples at $500{ }^{\circ} \mathrm{C}$ for $4 \mathrm{~h}$ in a muffle furnace (Thermolyne, Thermo Scientific; Waltham, MA, USA). Crude protein content was assessed by extracting total nitrogen using the micro-Kjeldahl technique, and protein was estimated using a conversion factor of 6.25 (Serviere-Zaragoza et al. 2002). Crude fat was determined by extraction with petroleum ether for $6 \mathrm{~h}$ in a Soxhlet equipment. The nitrogen-free extract (carbohydrate fraction) was obtained as the difference between measured components and total percentage of dry weights: $100-(\%$ moisture $+\%$ proteins $+\%$ lipids $+\%$ ash $)$.

\section{Fatty acid analyses}

Fatty acid composition was assessed according to the method described by Serviere-Zaragoza et al. (2015). Frozen fresh pooled subsamples were thawed, and lipids were extracted with chloroform/methanol (2:1 v/v) according to Folch et al. (1957). Fatty acids were transesterified with boron-trifluoridemethanol $\left(\mathrm{BF}_{3} 14 \%\right.$ methanol, Supelco), and methyl esters were analyzed in a gas chromatograph (GC, Agilent Technologies $6890 \mathrm{M}$ ) equipped with a DB-23 silica column $(30 \mathrm{~m} \times 0.25 \mathrm{~mm} \mathrm{ID} \times 0.25 \mu \mathrm{m}$ film thickness $)$ and a flame ionization detector with helium as the carrier gas $\left(0.7 \mathrm{~mL} \cdot \mathrm{min}^{-1}\right)$ (temperature ramp from 110 to $\left.220^{\circ} \mathrm{C}\right)$. Fatty acids were identified by comparing their retention times with those of standards (Sigma; Bellefonte, PA, USA), with the concentration of each fatty acid corrected for by correlation with the response of the corresponding standard. Data were analyzed using GC Chem Station Rev. A.10.02 (1757, Agilent Technologies, 2003).

\section{Analysis of sterols}

Total sterol composition was determined by gas chromatography according to Palacios et al. (2007) with some modifications. A fraction of total lipids previously extracted for fatty acid analysis was evaporated to dryness with $\mathrm{N}_{2}$, and sterols were transesterified with sodium methoxide at room temperature for $90 \mathrm{~min}$. Released sterols were extracted in hexane. Sterols were analyzed in a GC (Agilent Technologies $6890 \mathrm{M}$ ) equipped with a RTx-65 fused silica column (Crossbond diphenyl dimethyl polysiloxane) $(15 \mathrm{~m} \times 0.25 \mathrm{~mm} \mathrm{ID} \times$ $0.25 \mu \mathrm{m}$ film thickness) and a flame ionization detector with hydrogen as the carrier gas (50 psi constant pressure) (temperature ramp from 50 to $260{ }^{\circ} \mathrm{C}$ ). Sterols were identified by comparing their retention times with those of standards con agua marina y, una vez removidos los epibiontes y las partes necróticas, fueron transportadas en bolsas de plástico con hielo al laboratorio. La biomasa de las algas marinas frescas fue pesada, enjuagada con agua destilada, liofilizada (FreeZone Plus 4.5 Labconco; Kansas City, MO, EUA) y pulverizada $(0.6 \mathrm{~mm})$ con un molino comercial. Las muestras secas completas fueron almacenadas a $-70{ }^{\circ} \mathrm{C}$ para determinar la composición proximal, mientras que un subgrupo de muestras frescas fue utilizado para analizar la composición de lípidos y pigmentos.

\section{Análisis de la composición proximal}

Los contenidos de humedad, cenizas, proteína cruda y materia soluble en éter (lípidos) en todas las especies de algas marinas fueron determinados de acuerdo con lo descrito por la AOAC (2006). El contenido de humedad (\%) fue determinado secando $2 \mathrm{~g}$ de las algas frescas en un horno secador (Lindberg/blue, Thermo Scientific; Waltham, MA, EUA) a $105{ }^{\circ} \mathrm{C}$ hasta lograr un peso constante de la muestra. Para determinar el contenido de cenizas, se calcinaron las muestras a $500{ }^{\circ} \mathrm{C}$ por $4 \mathrm{~h}$ en una mufla (Thermolyne, Thermo Scientific; Waltham, MA, EUA). La proteína cruda fue determinada extrayendo el nitrógeno total de las muestras por la técnica micro-Kjeldahl, y el contenido de proteína fue estimado usando el factor de conversión 6.25 (Serviere-Zaragoza et al. 2002). El contenido de grasa cruda fue determinado por extracción durante $6 \mathrm{~h}$ usando éter de petróleo en un equipo Soxhlet. El extracto libre de nitrógeno (fracción de carbohidratos) se obtuvo por la diferencia entre los componentes determinados y el porcentaje total del peso seco: $100-(\%$ humedad $+\%$ proteínas $+\%$ lípidos $+\%$ ceniza $)$.

\section{Análisis de ácidos grasos}

La composición de ácidos grasos se determinó de acuerdo con el método descrito por Serviere-Zaragoza et al. (2015). Las submuestras de algas frescas fueron descongeladas, y los lípidos fueron extraídos con cloroformo/metanol $(2: 1 \mathrm{v} / \mathrm{v})$ de acuerdo con lo descrito por Folch et al. (1957). Los ácidos grasos fueron transesterificados con trifloruro de boro metanol ( $\mathrm{BF}_{3}$ 14\% metanol, Supelco), y los metil ésteres fueron analizados en un cromatógrafo de gases (CG, Agilent Technologies $6890 \mathrm{M}$ ) equipado con una columna capilar de sílice DB-23 $(30 \mathrm{~m} \times 0.25 \mathrm{~mm}$ DI $\times 0.25 \mu \mathrm{m}$ espesor de película) y un detector de ionización de flama con helio como gas acarreador $\left(0.7 \mathrm{~mL} \cdot \mathrm{min}^{-1}\right)$; la rampa de temperatura fue de 110 a $220^{\circ} \mathrm{C}$. Los ácidos grasos fueron identificados comparando los tiempos de retención con sus respectivos estándares (Sigma; Bellefonte, PA, EUA), y la concentración de cada ácido graso fue corregida mediante la correlación con la respuesta del estándar correspondiente. Los datos fueron analizados usando CG Chem Station Rev. A.10.02 (1757, Agilent Technologies, 2003). 
(Sigma; Bellefonte, PA, USA). Data were analyzed using GC Chem Station Rev. A.10.02 (1757, Agilent Technologies, 2003).

\section{Pigment composition}

Pigment composition was assessed according to the method described by Zapata et al. (2000) with the modifications described by Quintana-López et al. (2019). Briefly, fresh seaweed pooled samples were thawed, and 100-mg portions were homogenized on ice with $10 \mathrm{~mL}$ of acetone, avoiding light contact, and finally incubated at $4{ }^{\circ} \mathrm{C}$. After $24 \mathrm{~h}$, the supernatant was recovered by centrifugation $(3,200 \times \mathrm{g}$, $10 \mathrm{~min}$ at $4{ }^{\circ} \mathrm{C}$ ) and stored at $-70{ }^{\circ} \mathrm{C}$ until analysis. Pigments were analyzed using a high performance liquid chromatography (HPLC) system (Agilent Technologies 1200 Infinity Series) equipped with a ZORBAX C8 column $(4.6 \times 100 \mathrm{~mm}$, $3.5-\mu \mathrm{m}$ particle size) and a diode-array detector (DAD) at a wavelength of $440 \mathrm{~nm}$, with the temperature of the column kept at $25^{\circ} \mathrm{C}$. The mobile phases consisted of an eluent A, which was a mixture of methanol:acetonitrile: $0.25 \mathrm{M}$ aqueous pyridine solution $(50: 25: 25, \mathrm{~V}: \mathrm{V}: \mathrm{V})$, and an eluent $\mathrm{B}$, which was acetonitrile:acetone $(80: 20, \mathrm{~V}: \mathrm{V})$. Flow rate was fixed at $1 \mathrm{~mL} \cdot \mathrm{min}^{-1}$. All solvents used were HPLC grade (Tedia, OH, USA). Pigments were expressed as relative proportions and were identified by comparing their retention times with those of standards (DHI; Hoersholm, Denmark).

\section{Statistical analyses}

One-way analysis of variance (ANOVA) was performed to analyze gross chemical, fatty acid, sterol, and pigment composition data obtained from the seaweed specimens, followed by a post hoc Tukey test to assess significant differences $(P<0.05)$ between means. The percentage values were arcsine-transformed before analyses (Zar 1999), but results are expressed as untransformed means. Factor analysis (varimax normalized using principal components extraction) was used to extract the maximum variance from data sets of some biochemical components (fatty acids, sterols, and pigment content), with each principal component as a linear combination of most recognized bioactive compounds of seaweeds, considering factor loadings $\geq 0.7$ and eigenvalues $>1.0$. The data are reported as the mean \pm standard error. Analyses were run with Statistica v.13.0 (Statsoft).

\section{Results}

\section{Proximate composition}

Significant differences $(P<0.05)$ were observed in the crude protein and lipid compositions, nitrogen-free extract, ash, and moisture in the tissues of analyzed seaweed species (Table 1). The highest crude protein content was observed in C. sertularioides $(11.96 \% \pm 1.93$ dry weight

\section{Análisis de esteroles}

La composición total de esteroles fue determinada por cromatografía de gases de acuerdo con lo descrito por Palacios et al. (2007) con algunas modificaciones. Una fracción de la extracción de lípidos totales obtenida para el análisis de ácidos grasos fue evaporada a sequedad con $\mathrm{N}_{2}$, y los esteroles fueron transesterificados con metóxido de sodio por 90 min a temperatura ambiente. Los esteroles transesterificados fueron extraídos con hexano. Los esteroles fueron analizados en un CG (Agilent Technologies $6890 \mathrm{M}$ ) equipado con una columna de silice fundido RTx-65 (difenil dimetil polisiloxano Crossbond $)(15 \mathrm{~m} \times 0.25 \mathrm{~mm}$ DI $\times 0.25 \mu \mathrm{m}$ espesor de película) y un detector de ionización de flama con hidrógeno como gas acarreador (50 psi presión constante); la rampa de temperatura fue de 50 a $260^{\circ} \mathrm{C}$. Los esteroles se identificaron comparando sus tiempos de retención con sus respectivos estándares (Sigma; Bellefonte, PA, EUA. Los datos fueron analizados usando CG Chem Station Rev. A.10.02 (1757, Agilent Technologies, 2003).

\section{Composición de pigmentos}

La composición de pigmentos fue determinada de acuerdo con el método descrito por Zapata et al. (2000) con las modificaciones descritas en Quintana-López et al. (2019). Brevemente, las submuestras frescas de algas marinas fueron descongeladas, homogenizadas en porciones de $100 \mathrm{mg}$ sobre hielo en $10 \mathrm{~mL}$ de acetona, evitando en todo momento el contacto con la luz, y finalmente incubadas a $4{ }^{\circ} \mathrm{C}$. Después de $24 \mathrm{~h}$, el sobrenadante fue recuperado por centrifugación $\left(3,200 \times \mathrm{g}, 10 \mathrm{~min}\right.$ a $\left.4{ }^{\circ} \mathrm{C}\right) \mathrm{y}$, posteriormente, almacenado a $-70{ }^{\circ} \mathrm{C}$ hasta su análisis. Los pigmentos fueron analizados en un cromatógrafo de líquidos de alta resolución (Agilent Technologies 1200 Infinity Series) equipado con una columna ZORBAX C8 $(4.6 \times 100 \mathrm{~mm}, 3.5 \mu \mathrm{m}$ tamaño de partícula) y un detector de arreglo de diodos a una longitud de onda de $440 \mathrm{~nm}$; la temperatura de la columna se mantuvo a $25^{\circ} \mathrm{C}$. Las fases móviles consistieron en un eluente $\mathrm{A}$, que es una mezcla de metanol:acetonitrilo:0.25 $\mathrm{M}$ de piridina en solución $(50: 25: 25, \mathrm{~V}: \mathrm{V}: \mathrm{V})$, y un eluente $\mathrm{B}$, que es una mezcla de acetonitrilo:acetona $(80: 20, \mathrm{~V}: \mathrm{V})$. El flujo se mantuvo constante a $1 \mathrm{~mL} \cdot \mathrm{min}^{-1}$. Todos los solventes fueron de grado cromatográfico (Tedia, OH, EUA). Los pigmentos fueron expresados en proporción relativa y fueron identificados comparando su tiempo de retención con el tiempo de retención de los estándares (DHI; Hoersholm, Dinamarca).

\section{Análisis estadísticos}

Se realizó el análisis de varianza (ANDEVA) de una vía para analizar los datos de la composición proximal, ácidos grasos, esteroles y pigmentos de las especies de algas marinas utilizadas, seguido de una prueba a posteriori de Tukey para determinar las diferencias significativas $(P<0.05)$ entre 
[dw]), while the lowest values were found in U. expansa and P. durvillaei $(4.12 \% \pm 0.51$ and $5.87 \% \pm 0.12 \mathrm{dw}$, respectively); intermediate values were found in S. filamentosa and G. vermiculophylla ( $10.4 \% \mathrm{dw}$, on average).

Lipid contents varied significantly $(P<0.05)$ among the seaweed species analyzed (Table 1). The highest lipid content was found in $R$. riparium $(1.50 \% \pm 0.01 \mathrm{dw})$ and the lowest in S. filamentosa, G. vermiculophylla $(0.26 \% \pm 0.01$ and $0.36 \% \pm$ $0.01 \mathrm{dw}$, respectively), and P. durvillaei $(0.37 \% \pm 0.03 \mathrm{dw})$.

Significant $(P<0.05)$ differences were observed in the ash contents of seaweed specimens (Table 1). The highest content was observed in $R$. riparium $(39.08 \% \pm 2.59 \mathrm{dw})$ and the lowest in P. durvillaei and C. isabelae $(24.47 \% \pm 0.02$ and $28.90 \% \pm 0.30 \mathrm{dw}$, respectively); intermediate values were observed in the remaining seaweed species.

Moisture content was significantly $(P<0.05)$ different among the seaweed species analyzed (Table 1). Values were within the range of $83-93 \%$, with the highest values for C. isabelae and the lowest for P. durvillaei and U. expansa.

\section{Fatty acids}

All fatty acids significantly $(P<0.05)$ varied among the seaweed species analyzed (Table 2). All seaweed species had 16:0 as the major fatty acid, with the highest value in G. vermiculophylla and the lowest in R. riparium $(64.51 \% \pm$ 0.82 and $29.17 \% \pm 5.15)$. The content of polyunsaturated fatty acids (PUFAs) was highest in $R$. riparium $(45.19 \% \pm$ 10.64), with important contributions of $18: 2 \mathrm{n}-6(23.42 \% \pm$ $0.49), 18: 3 n-3(13.57 \% \pm 7.03), 20: 4 n-6(2.45 \% \pm 0.33)$, and $20: 5 \mathrm{n}-3(2.87 \% \pm 1.70)$. The lowest PUFA content $(38.99 \%$ $\pm 0.64)$ was observed in $C$. sertularioides, with contributions of $18: 2 \mathrm{n}-6(13.50 \% \pm 0.67), 18: 3 \mathrm{n}-3(16.72 \% \pm 0.71)$, $20: 4 n-6(1.76 \% \pm 0.07)$, and $20: 5 n-3(3.75 \pm 0.04)$. In P. durvillaei, PUFA content was $22.94 \% \pm 0.38$, with lower contents of $18: 2 \mathrm{n}-6(3.90 \% \pm 0.05)$ and $18: 3 \mathrm{n}-3(3.34 \% \pm$ $0.05)$, but higher content of $20: 4 \mathrm{n}-6(8.87 \% \pm 0.09)$, and a value of $20: 5 n-3(2.18 \% \pm 0.12)$ similar to those previously reported for other seaweeds. The highest 22:6n-3 content $(8.90 \% \pm 2.19)$ was found in $S$. filamentosa, with significantly $(P<0.05)$ lower values for the remaining seaweed species. The content of highly unsaturated fatty acids (HUFAs) was observed within the range of $1-11 \%$, with the highest values for P. durvillaei and S. filamentosa, followed by $C$. sertularioides, $R$. riparium, and C. isabelae, and the lowest values for $G$. vermiculophylla and U. expansa. The polyunsaturation index (PUI) showed higher availability of polyunsaturated fatty acids in $R$. riparium, C. sertularioides, and P. durvillaei (118-138) than in the remaining seaweed species (Table 2).

\section{Sterols}

Significant $(P<0.05)$ differences were observed in the sterol contents of the seaweeds analyzed (Table 3). The las medias. Los valores de porcentaje fueron transformados a arcoseno previo al análisis (Zar 1999), aunque los resultados están expresados sin transformar. Se realizó un análisis de factores (varimax normalizada usando la extracción de componentes principales) para extraer la máxima varianza de los datos de algunos de los componentes bioquímicos (ácidos grasos, esteroles y pigmentos), con cada componente como una combinación lineal de los compuestos bioactivos de algas marinas más reconocidos, y se consideraron los factores de peso de $\geq 0.7$ y eigenvalores de $>1.0$. Los valores están reportados como la media \pm error estándar. Los análisis se realizaron con Statistica v.13.0 (Statsoft).

\section{RESUltados}

\section{Composición proximal}

Se observaron diferencias significativas $(P<0.05)$ en los contenidos de proteína cruda y composición de lípidos, el extracto libre de nitrógeno, la ceniza y la humedad en los tejidos de las algas marinas analizadas (Tabla 1). El valor más alto de proteína cruda se observó en $C$. sertularioides $(11.96 \% \pm 1.93$ peso seco [ps]), mientras que los valores más bajos se encontraron en $U$. expansa y P. durvillaei $(4.12 \% \pm$ 0.51 y $5.87 \% \pm 0.12 \mathrm{ps}$, respectivamente); los valores intermedios se encontraron en S. filamentosa y G. vermiculophylla (10.4\% ps, en promedio).

El contenido de lípidos varió significativamente $(P<0.05)$ entre las especies de algas marinas analizadas (Tabla 1). El contenido de lípidos más alto se encontró en $R$. riparium $(1.50 \% \pm 0.01 \mathrm{ps})$ y el menor en $S$. filamentosa, G. vermiculophylla $(0.26 \% \pm 0.01$ y $0.36 \% \pm 0.01 \mathrm{ps}$, respectivamente) y $P$. durvillaei $(0.37 \% \pm 0.03 \mathrm{ps})$.

Se observaron diferencias significativas $(P<0.05)$ en el contenido de ceniza de las algas marinas seleccionadas (Tabla 1). El contenido más alto se observó en $R$. riparium $(39.08 \% \pm 2.59 \mathrm{ps})$ y el más bajo en P. durvillaei y C. isabelae $(24.47 \% \pm 0.02$ y $28.90 \% \pm 0.30 \mathrm{ps}$, respectivamente); los valores intermedios se observaron en el resto de las especies de algas marinas.

El contenido de humedad fue significativamente diferente $(P<0.05)$ entre las algas marinas (Tabla 1$)$. Los valores observados estuvieron en el intervalo de $83-93 \%$, con el valor más alto para $C$. isabelae y los más bajos para $P$. durvillaei y U. expansa.

\section{Ácidos grasos}

Todos los ácidos grasos variaron significativamente $(P<0.05)$ entre las algas marinas analizadas (Tabla 2). En todas las especies de algas marinas se encontró como ácido graso mayoritario el 16:0, con el valor más alto en G. vermiculophylla y el menor en $R$. riparium $(64.51 \% \pm$ 0.82 y $29.17 \% \pm 5.15)$. El contenido de ácidos grasos poliinsaturados (AGPI) fue mayor en $R$. riparium $(45.19 \% \pm$ 


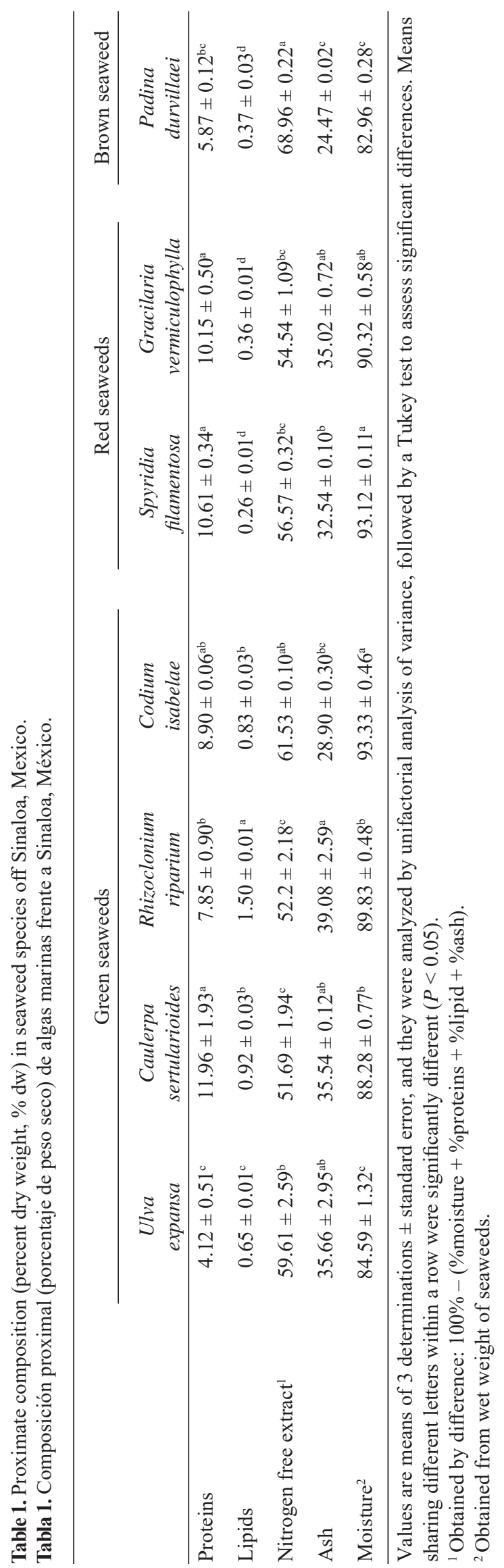




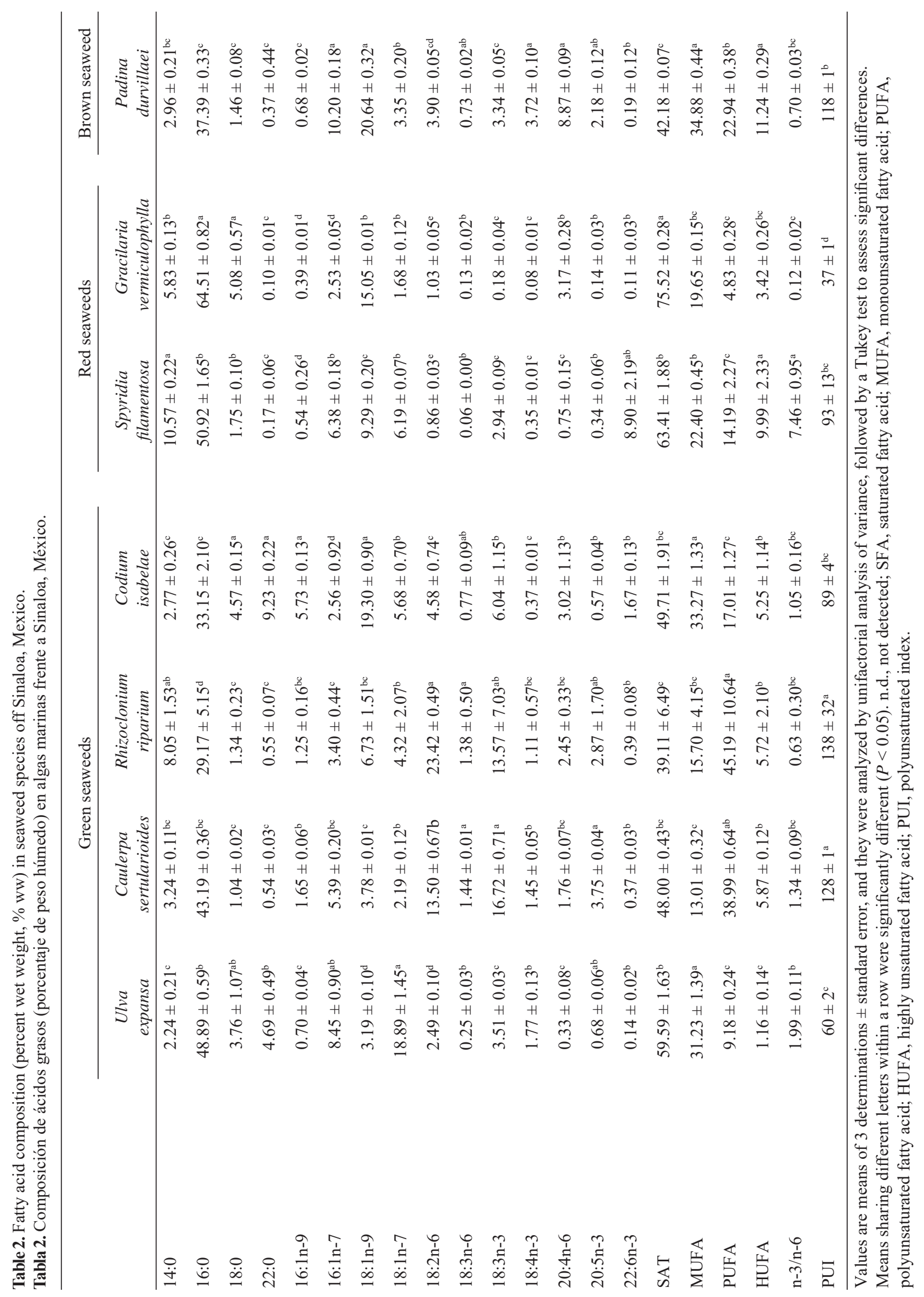


Osuna-Ruiz et al.: Biochemical composition of tropical seaweed species

highest cholesterol+dehydrocholesterol contents (>90\%) were found in S. filamentosa and G. vermiculophylla. In contrast, $\beta$-sitosterol was the major sterol $(71-77 \%)$ in $C$. sertularioides, $R$. riparium, and C. isabelae. Among seaweed species, stigmasterol was highest in $R$. riparium (14\%) and was identified as the second most important sterol in this species. In U. expansa and P. durvillaei, the major sterols were fucosterol+isofucosterol (79\%), which are geometric isomers that are indistinguishable by the performed method (Jonker et al. 1985), and the signal of both compounds appeared at same retention time.

\section{Pigments}

All identified pigments varied significantly $(P<0.05)$ among the seaweed species analyzed (Table 4$)$. The 2 major pigments found in all seaweed species were chlorophyll $a$ and $b$. The former was particularly higher in G. vermiculophylla $(60.27 \% \pm 7.27)$, followed by S. filamentosa, P. durvillaei, $U$. expansa, and C. sertularioides (39-48\%), and the lowest values were found in $R$. riparium and C. isabelae (31-33\%). Chlorophyll $b$ was higher in all green seaweeds (28-43\%) and lower in S. filamentosa $(<3 \%)$; it was not detected in G. vermiculophylla and P. durvillaei. Lutein content was found in considerable proportions in S. filamentosa, U. expansa, and R. riparium (33\%, $18 \%$, and $16 \%$, respectively). Chlorophyllide $a(25 \%)$ and fucoxanthin (34\%) were found in considerable proportions in G. vermiculophylla and P. durvillaei, respectively. The $\beta$-carotene content values were within the range of 1.9-10.0\%, with higher proportions in S. filamentosa and G. vermiculophylla, but it was not detected in C. isabelae (Table 4).

\section{Biochemical composition obtained from principal component analysis}

Fatty acids, sterols, and pigments are useful biomarkers for the identification of seaweed species within each taxonomic group. The use of some of the biochemical components not only allows discrimination among assessed variables but also helps cluster or group seaweed species according to common variability in their biochemical composition. Factor analysis showed that the variation of the selected biochemical components was described by 3 principal components (Table 5). The first component explained $39.3 \%$ of total variance, with significant contributions of chlorophyll $a$ and $\beta$-carotene (both with 0.79$), \beta$-sitosterol $(-0.90)$, total PUFAs $(-0.72)$, and chlorophyll $b(-0.88)$. The second component explained $22.3 \%$ of total variance and had significant and inverse contributions of $20: 4 n-6(-0.70), 20: 5 n-3(-0.70)$, and total HUFA (-0.87). The third component explained $18.5 \%$ of total variance and had significant contributions of 22:6n-3 (0.76) and fucosterol+isofucosterol $(-0.79)$ (Table 5). The factor scores obtained with the selected biochemical compounds showed common variability in G. vermiculophylla
10.64), con importantes contribuciones del 18:2n-6 (23.42\% $\pm 0.49), 18: 3 \mathrm{n}-3(13.57 \% \pm 7.03), 20: 4 \mathrm{n}-6(2.45 \% \pm 0.33)$ y $20: 5 \mathrm{n}-3(2.87 \% \pm 1.70)$. El menor contenido de AGPI se observó en C. sertularioides, con contribución importante de $18: 2 \mathrm{n}-6(13.50 \% \pm 0.67), 18: 3 \mathrm{n}-3(16.72 \% \pm 0.71), 20: 4 \mathrm{n}-6$ $(1.76 \% \pm 0.07)$ y $20: 5 n-3(3.75 \% \pm 0.04)$. En P. durvillaei, el contenido de AGPI fue de $22.94 \% \pm 0.38$, con menor contenido de $18: 2 \mathrm{n}-6(3.90 \% \pm 0.05)$ y $18: 3 \mathrm{n}-3(3.34 \% \pm 0.05)$, pero un valor alto de $20: 4 \mathrm{n}-6(8.87 \% \pm 0.09)$ y un valor similar al presentado por las especies anteriores de 20:5n-3 $(2.18 \% \pm 0.12)$. El valor más alto de $22: 6 n-3(8.90 \% \pm 2.19)$ se encontró en $S$. filamentosa, con valores significativamente $(P<0.05)$ menores para el resto de las especies de algas marinas. El contenido de los ácidos grasos altamente insaturados (AGAI) se observó en un intervalo del $1 \%$ a $11 \%$, con el valor más alto en $P$. durvillaei y $S$. filamentosa, seguido de $C$. sertularioides, $R$. riparium y $C$. isabelae, mientras que los más bajos se observaron en $G$. vermiculophylla y U. expansa. El índice de poliinsaturación (IPI) mostró un valor más alto para $R$. riparium, $C$. sertularioides y $P$. durvillaei (118-138) que en el resto de las especies de algas marinas (Tabla 2).

\section{Esteroles}

Se observaron diferencias significativas $(P<0.05)$ en el contenido de esteroles de las algas marinas analizadas (Tabla 3). El mayor contenido de colesterol+dehidrocolesterol $(>90 \%)$ se encontró en S. filamentosa y G. vermiculophylla. En contraste, el $\beta$-sitosterol fue el esterol que se encontró mayoritariamente en $C$. sertularioides, $R$. riparium y $C$. isabelae. El estigmasterol fue más alto en $R$. riparium (14\%) y fue identificado como el segundo esterol más importante en esta especie. Los esteroles mayoritarios en U. expansa y $P$. durvillaei fueron fucosterol+isofucosterol (79\%), los cuales son isómeros geométricos que son indistinguibles por el método aplicado (Jonker et al. 1985), y la señal de ambos compuestos apareció en el mismo tiempo de retención.

\section{Pigmentos}

Todos los pigmentos identificados variaron significativamente entre las especies de algas marinas analizadas (Tabla 4). Los pigmentos mayoritarios encontrados en todas las especies de algas marinas fueron la clorofila $a$ y $b$. La primera fue particularmente alta en G. vermiculophylla $(60.27 \% \pm 7.27)$, seguida de S. filamentosa, P. durvillaei, U. expansa y C. sertularioides (39-48\%), y los menores valores se encontraron en R. riparium y C. isabelae (31-33\%). La clorofila $b$ fue mayor en todas las especies de algas marinas verdes $(28-43 \%)$ y menor en S. filamentosa $(<3 \%)$; no se detectó en $G$. vermiculophylla y $P$. durvillaei. El contenido de luteína se encontró en cantidades considerables en $S$. filamentosa, $U$. expansa y $R$. riparium (33\%, $18 \%$ y $16 \%$, respectivamente). Los contenidos de clorofilide $a(25 \%)$ y fucoxantina (34\%) se encontraron en proporciones considerables en $G$. vermiculophylla y 
and S. filamentosa, while a similar composition was obtained with $C$. sertularioides, $R$. riparium, and $C$. isabelae. In contrast, the compositions of $U$. expansa and $P$. durvillaei were distinctive when compared with the other seaweed species analyzed (Fig. 1).

\section{Discussion}

In Mexico, the biochemical compositions of some seaweed species in the Gulf of Mexico and the northeastern Pacific Ocean have been assessed, but none of the seaweed species distributed in the lower tropical region of the Gulf of California and the Pacific Ocean, particularly those from lagoons in Sinaloa, Mexico, have been evaluated. Gross chemical composition is useful for establishing not only the nutritional value of seaweeds but also that of specific components like fatty acids, sterols, and pigments, which could also be useful as biomarkers for establishing specific variations in seaweeds between biogeographic regions. The differences in the contents of biochemical components could be attributed to several intrinsic factors, such as species-specific variations, reproductive stage, and the portion of thallus analyzed, and extrinsic factors, mainly sample size, analytical technique applied, unattached epibionts or epiphytes, and the specific climatic conditions at each sampling site.

The nutritional value of the seaweeds assessed in this study showed that crude protein contents were $4-12 \%$, $10 \%$, and $6 \%$ for green, red, and brown seaweeds, respectively (Table 1). These values were lower than those observed in similar tropical species ( $U$. expansa and Ulva lobata, 21-22\%; Colpomenia tuberculata and P. durvillaei, 11\%; and G. vermiculophylla, 23\%; Peraza-Yee 2014). Compared with seaweeds inhabiting the temperate zone of the northeastern Pacific coast of Mexico, seasonal contents of crude proteins are in the range of $10-15 \%$ for Eisenia arborea, $8-14 \%$ for Macrocystis pyrifera, and 19-21\% for Gelidium robustum (Serviere-Zaragoza et al. 2002). In contrast to variations in crude protein contents, the levels of total lipids, carbohydrates, and ashes were in a range $(0.26-1.50 \%, 52-69 \%$, and $25-39 \%$, respectively) comparable with other tropical ( $0.46-$ $1.02 \%, 50-73 \%$, and $19-34 \%$, respectively; Peraza-Yee 2014) and temperate $(0.3-1.1 \%, 46-68 \%$, and $7-38 \%$, respectively; Serviere-Zaragoza et al. 2002) seaweed species. Aside from the intrinsic and extrinsic factors mentioned above that could explain the differences observed in protein contents, the conventional nitrogen-to-protein conversion factor (NPF) of 6.25 should be considered, as it usually tends to overestimate protein levels. We decided to use this NPF to compare our results with those in the studies mentioned above. Nevertheless, when the specific NPF of 5 suggested for different species of seaweeds (Lourenço et al. 2002, Angell et al. 2016) was applied to data for seaweeds analyzed in this study, protein levels were lower ( $1 \%$ to $3 \%$ ) compared with the levels obtained with the conventional NPF (Table 1).
P. durvillaei, respectivamente. El contenido de $\beta$-caroteno se encontró en el intervalo de 1.9-10.0\%, con la mayor proporción en S. filamentosa y G. vermiculophylla, pero no se detectó en C. isabelae (Tabla 4).

\section{Composición bioquímica por análisis de componentes principales}

Los ácidos grasos, esteroles y pigmentos son de gran utilidad como biomarcadores para identificar a las algas marinas dentro de su grupo taxonómico. El uso de algunos de los componentes bioquímicos sirve tanto para discriminar entre las variables analizadas como para agrupar a las especies de algas marinas de acuerdo con la variabilidad común en su composición bioquímica. El análisis de factores mostró que la variación de los componentes bioquímicos seleccionados se describió por 3 componentes principales (Tabla 5). El primer componente explicó el $39.3 \%$ de la varianza total, con contribución significativa de la clorofila $a$ y el $\beta$-caroteno (ambos con 0.79), el $\beta$-sitosterol (-0.90), el total de AGPI $(-0.72)$ y la clorofila $b(-0.88)$. El segundo componente explicó el $22.3 \%$ de la varianza total, con una contribución significativa inversa del 20:4n-6 (-0.70), 20:5n-3 (-0.70) y AGAI total (-0.87). El tercer componente explicó el 18.5\% del total de la varianza, con una contribución significativa del 22:6n-3 (0.76) y el fucosterol+isofucosterol (-0.79) (Tabla 5). Las puntuaciones factoriales obtenidas de la selección de los compuestos bioquímicos mostraron una variabilidad común en G. vermiculophylla y S. filamentosa, mientras que la composición obtenida fue similar en $C$. sertularioides, $R$. riparium y C. isabelae. En contraste, U. expansa y P. durvillaei mostraron una composición bioquímica distintiva en comparación con las otras especies de algas marinas (Fig. 1).

\section{Discusión}

En México, se ha evaluado la composición bioquímica en algunas especies de algas marinas del golfo de México y el noroeste del océano Pacífico, pero no en las algas que se distribuyen en las regiones tropicales del golfo de California y el océano Pacífico, particularmente, las de las lagunas en Sinaloa, México. La composición química proximal es una herramienta útil para establecer el valor nutricional de las algas marinas y de los componentes más específicos como los ácidos grasos, esteroles y pigmentos, los cuales pueden resultar de gran utilidad para establecer variaciones específicas en la composición de las algas marinas entre diferentes regiones biogeográficas. La diferencia en los contenidos de los componentes bioquímicos pueden atribuirse a diferentes factores intrínsecos, como las variaciones especie-específicas, la etapa reproductiva y la porción del talo utilizado, y a algunos factores extrínsecos, principalmente el tamaño de la muestra analizada, la técnica analítica aplicada, el desprendimiento de epibiontes o epífitas y las condiciones climáticas específicas prevalentes en cada sitio de muestreo. 


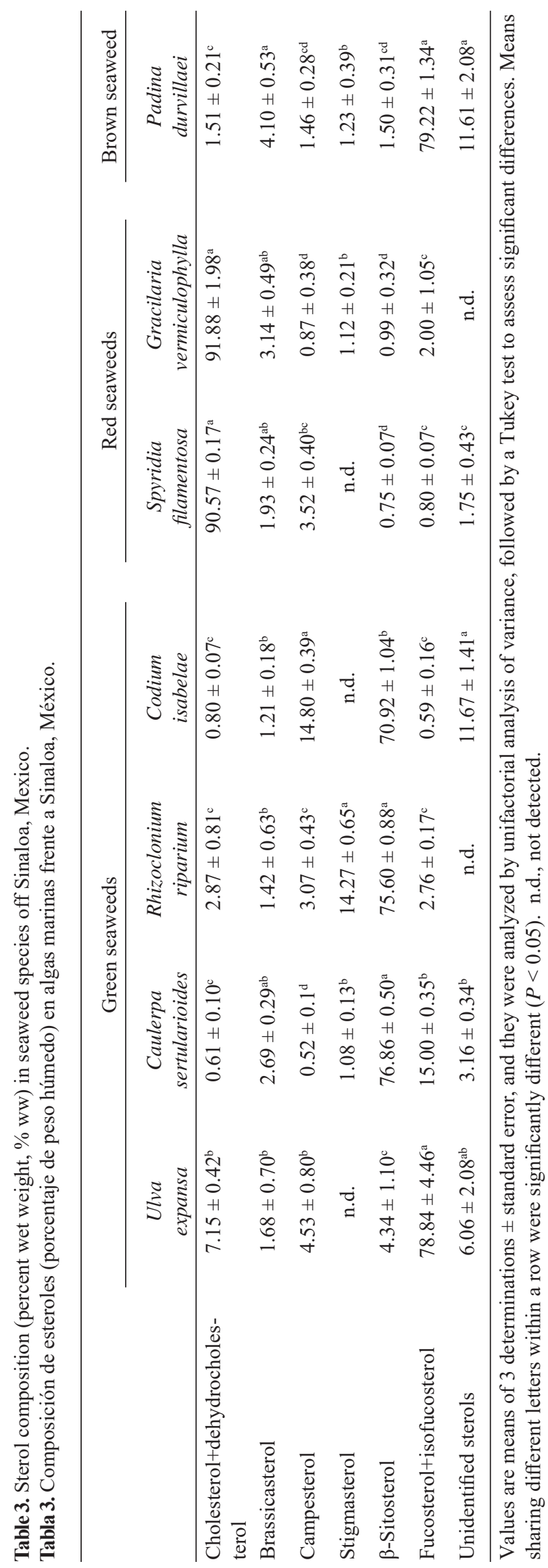


Ciencias Marinas, Vol. 45, No. 3, 2019

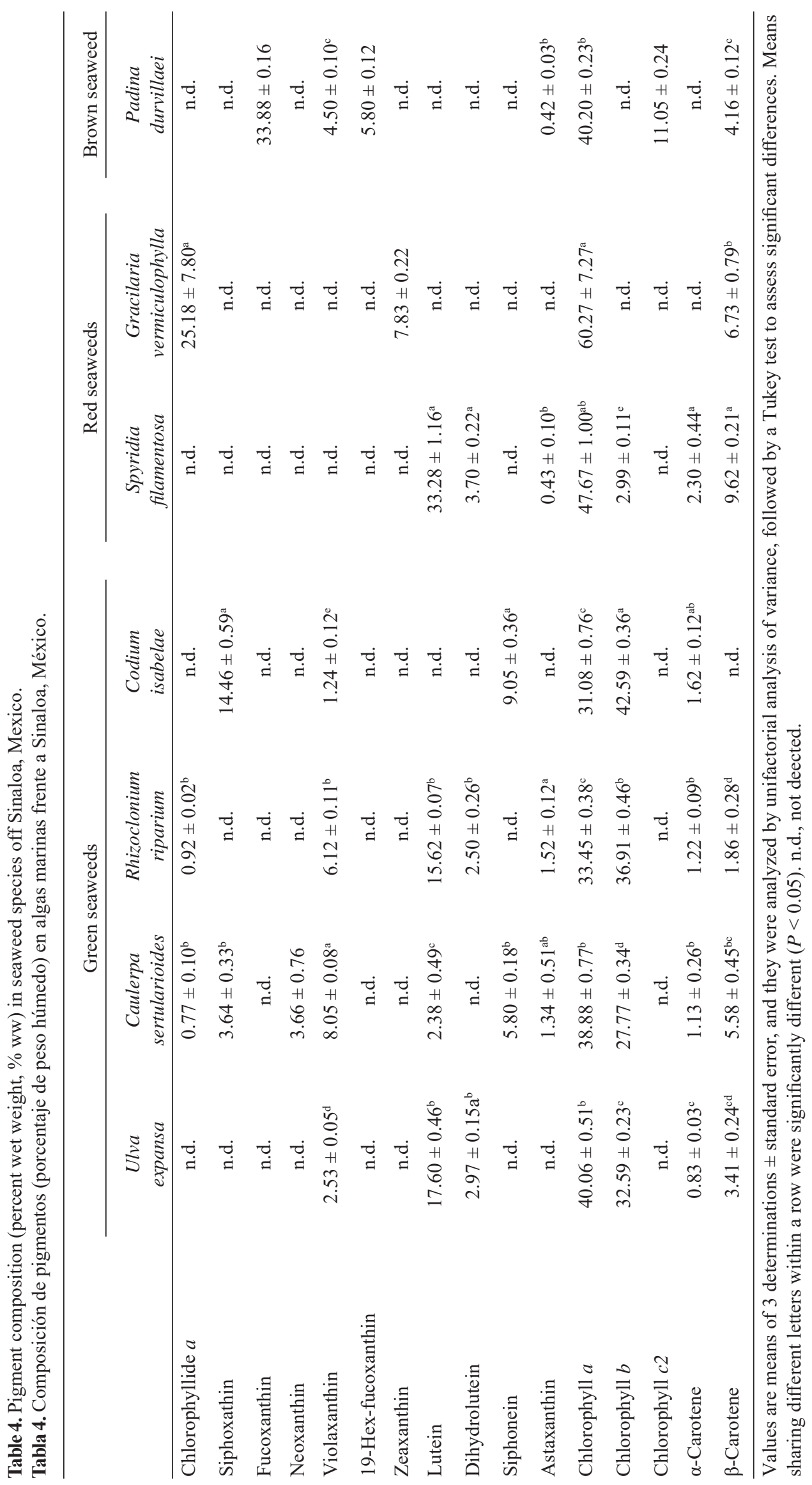


Table 5. Factor loadings (verimax normalized) using principal component extraction. Tabla 5. Factores de peso (verimax normalizada) estimados mediante el uso de componentes principales.

\begin{tabular}{|c|c|c|c|}
\hline Variation & Factor 1 & Factor 2 & Factor 3 \\
\hline$\beta$-sitosterol & -0.90 & 0.01 & 0.27 \\
\hline Fucosterol + isofucosterol & 0.14 & -0.18 & -0.79 \\
\hline $20: 4 n-6$ & 0.12 & -0.70 & -0.54 \\
\hline $20: 5 n-3$ & -0.58 & -0.70 & 0.02 \\
\hline $22: 6 n-3$ & 0.41 & -0.10 & 0.76 \\
\hline PUFA & -0.72 & -0.57 & 0.23 \\
\hline HUFA & 0.19 & -0.87 & 0.28 \\
\hline Chlorophyll $a$ & 0.79 & 0.03 & -0.06 \\
\hline Chlorophyll $b$ & -0.88 & 0.40 & 0.01 \\
\hline$\beta$-carotene & 0.79 & -0.17 & 0.38 \\
\hline Eigenvalue & 3.90 & 2.20 & 1.80 \\
\hline Total variance $(\%)$ & 39.30 & 22.30 & 18.50 \\
\hline Cumulative eigenvalue & 3.90 & 6.20 & 8.00 \\
\hline Cumulative variance (\%) & 39.30 & 61.70 & 80.20 \\
\hline
\end{tabular}

Bold loadings are significant ( $\geq 0.7$ ). PUFA, polyunsaturated fatty acids; HUFA, highly unsaturated fatty acids.

Although total lipid contents were similar between tropical and temperate seaweed species, some important differences were observed in fatty acid composition. Lower PUFA contents (Table 2) were obtained for the tropical red seaweeds, S. filamentosa and G. vermiculophylla (14\% and $5 \%$, respectively), compared with the seasonal contents observed for the temperate species, Gracilaria sp. (46-55\%) and Gellidium robustum (38-42\%) (Serviere-Zaragoza et al. 2014). In the 4 tropical green seaweeds, PUFA content values were in the range of $9-45 \%$ (Table 2), with increasing values among species as follows: U. expansa, $C$. isabelae, C. sertularioides, and $R$. riparium. These values are in the range of those reported for the tropical seaweeds $U$. expansa and $U$. lobata in the summer (15-28\%) and winter (38-48\%) seasons (Peraza-Yee 2014). Interestingly, PUFA content $(16-48 \%)$ in the temperate seaweed Ulva lactuca was not different from the contents in the tropical species of the same genera (Serviere-Zaragoza et al. 2014). For the brown seaweed, P. durvillaei, Peraza-Yee (2014) reported the same content of saturated fatty acids (c.a. $42 \%$ ) but higher contents of monounsaturated fatty acids (25\%) and PUFAs (34\%), compared with the contents reported in the present study. This could be due to differences in the harvest season but also to differences in environmental factors (i.e., temperature, nutrient availability, and salinity (Guschina and Harwood 2006). Further investigations are needed to establish seasonal variations and the effect of specific environmental factors for comparing the
El valor nutricional de las algas marinas determinado en este trabajo muestra que los contenidos de proteína cruda se encontraron en $4-12 \%, 10 \%$ y $6 \%$ para las algas verdes, las algas rojas y el alga café, respectivamente (Tabla 1). Estos valores fueron menores comparados con los observados en especies tropicales similares (U. expansa y Ulva lobata, 21-22\%; Colpomenia tuberculata y P. durvillaei, $11 \%$; y G. vermiculophylla, 23\%; Peraza-Yee 2014). En comparación con las algas marinas que habitan en zonas templadas de la costa mexicana del Pacífico nororiental, los contenidos estacionales de proteína cruda se encontraron en el intervalo de 10-15\% para Eisenia arborea, 8-14\% Macrocystis pyrifera y $19-21 \%$ para Gelidium robustum (Serviere-Zaragoza et al. 2002). En contraste con las variaciones en el contenido de proteína cruda, el nivel de lípidos totales, los carbohidratos y las cenizas estuvieron en un intervalo $(0.26-1.50 \%, 52-69 \%$ y $25-39 \%$, respectivamente) comparable con los valores obtenidos para otras especies de algas tropicales (0.46$1.02 \%, 50-73 \%$ y $19-34 \%$, respectivamente; Peraza-Yee 2014) y de zonas templadas $(0.3-1.1 \%, 46-68 \%$ y $7-38 \%$, respectivamente; Serviere-Zaragoza et al. 2002). Además de los factores intrínsecos y extrínsecos mencionados anteriormente que podrían explicar las diferencias observadas en el contenido de proteínas, debe considerarse el factor convencional de 6.25 para la conversión de nitrógeno a proteína (FNP), ya que generalmente tiende a sobreestimar los niveles de proteínas. Decidimos usar este FNP para comparar nuestros resultados con los valores reportados en los estudios 
biochemical composition of these seaweeds between temperate and tropical environments.

The nutritional value of seaweeds in relation to fatty acid composition, particularly those with $\geq 20$ carbons and the n-3 series, should also be considered. All seaweed species had 20:5n-3 (eicosapentaenoic acid) and 22:6n-3 (docosahexaenoic acid), fatty acids with known high nutritional value, which could particularly be attributed to the green seaweeds $C$. sertularioides and $R$. riparium and the brown seaweed $P$. durvillaei. The red seaweed $S$. filamentosa had the highest nutritional value because of its higher 22:6n-3 content $(8.9 \%$ ), while G. vermiculophylla showed the lowest since it had the lowest 20:5n-3 and 22:6n-3 contents. In general, Rhodophyta has been identified as a good source of 20:5n-3; however, the content of this PUFA is highly variable (Khotimchenko and Gusarova 2004, Kumari et al. 2010, Imbs et al. 2012, Pereira et al. 2012). The seasonal variation of 22:6n-3 in S. filamentosa off Turkey showed values of $0.69 \%$ for the spring and $3.82 \%$ for the summer (Polat and Ozogul 2013). For the tropical red seaweeds Ahnfeltia plicata, Hypnea musciformis, and Hypnea esperi, the reported $22: 6 \mathrm{n}-3$ contents were $0.75 \%, 0.96 \%$, and $1.56 \%$, respectively, while the $22: 6 n-3$ contents reported for 4 brown and 9 green seaweed species were within the range of $0.05-0.78 \%$ and $0.81-5.81 \%$, respectively (Kumari et al. 2010). The PUFA content in C. sertularioides determined in this study was similar to those reported for 3 different Caulerpa species (39\% vs $29-38 \%$, respectively), though the content of $22: 6 n-3$ was lower $(0.37 \%$ vs $2.8-3.6 \%$, respectively), and the 20:5n-3 assessed in C. sertularioides $(3.75 \%)$ was not observed in the other 3 Caulerpa species (Nagappan and Vairappan 2014). mencionados anteriormente. Sin embargo, cuando se usó el FNP específico de 5 sugerido para diferentes especies de algas marinas (Lourenço et al. 2002, Angell et al. 2016) en los datos de las algas marinas analizadas en este trabajo, los niveles de proteínas disminuyeron en un intervalo de $1 \%$ a $3 \%$ en comparación con los niveles obtenidos con el FNP convencional de 6.25 (Tabla 1).

Aunque el contenido de lípidos totales fue similar entre las especies de algas marinas de zonas tropicales y templadas, se observaron algunas diferencias importantes en la composición de ácidos grasos. Se observó un menor contenido de AGPI en las algas rojas tropicales S. filamentosa y G. vermiculophylla ( $14 \%$ y $5 \%$, respectivamente), en comparación con las variaciones estacionales de las algas rojas de las zonas templadas, Gracilaria sp. (46-55\%) y Gellidium robustum (38-42\%) (Serviere-Zaragoza et al. 2014). En las 4 especies tropicales de algas verdes, el contenido de AGPI se encontró en el intervalo de 9-45\% (Tabla 2); los valores incrementaron en el siguiente orden: U. expansa, C. isabelae, $C$. sertularioides y $R$. riparium. Estos valores se encuentran dentro de los intervalos determinados previamente para las algas marinas tropicales $U$. expansa y $U$. lobata obtenidos durante las temporadas de verano (15-38\%) e invierno (38-48\%) (Peraza-Yee 2014). Resulta interesante que el contenido de AGPI (16-48\%) obtenido para el alga marina Ulva lactuca de zonas templadas no difirió del obtenido para las especies tropicales del mismo género (Serviere-Zaragoza et al. 2014). Peraza-Yee (2014) reportó el mismo contenido de ácidos grasos saturados (c.a. $42 \%$ ), pero un mayor contenido de ácidos grasos monoinsaturados (25\%) y de AGPI (34\%) para el alga marina café $P$. durvillaei, lo cual es comparable con lo observado en el presente estudio. Esto puede deberse

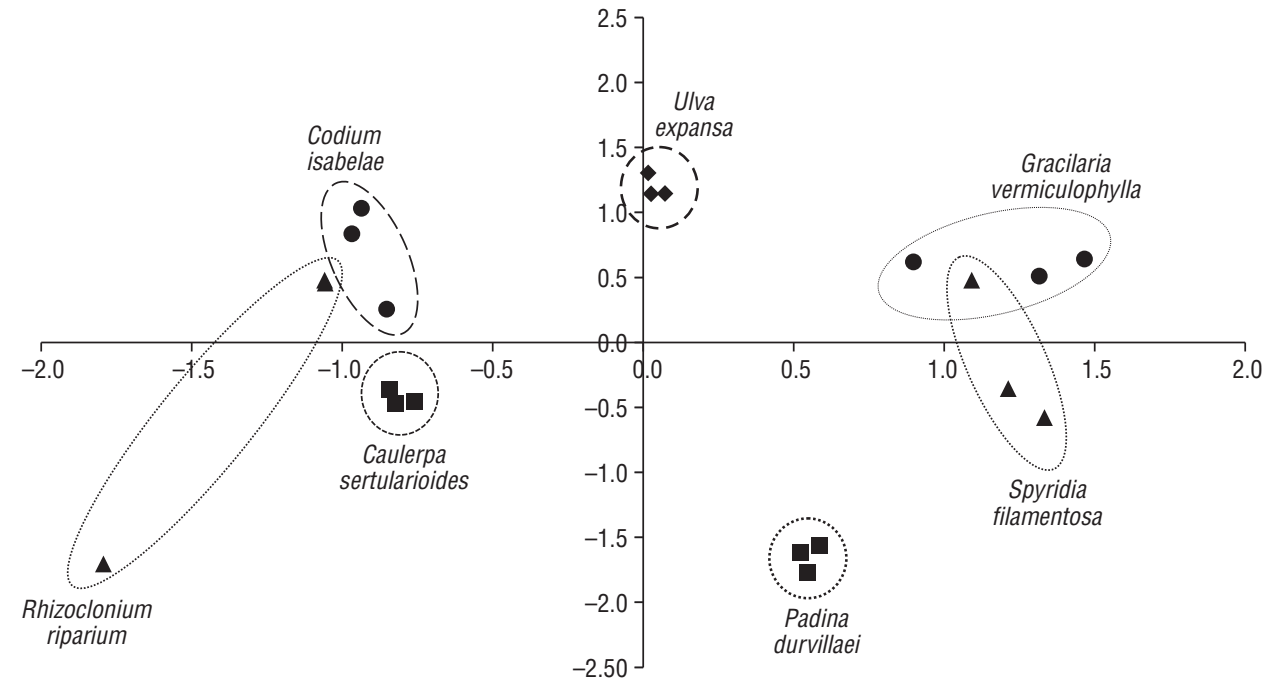

Figure 1. Bioactive composition using factor scores with select biochemical components in seaweed species off Sinaloa, Mexico. Each point is a replicate sample. The different circles indicate common variability between species.

Figura 1. Composición bioactiva usando los factores de peso con algunos de los componentes bioquímicos determinados en las algas marinas de Sinaloa, México. Cada punto corresponde a una réplica. Los diferentes círculos indican la variabilidad común entre especies. 
The World Health Organization has recommended a ratio of $n-3 / n-6 \geq 1$ for the prevention of several cardiovascular disorders, inflammatory diseases, and cancer (Simopoulos 2009, Gómez-Candela et al. 2011). Taking into account the $\mathrm{n}-3 / \mathrm{n}-6$ ratios and the PUI, which indicates the degree of unsaturation of fatty acids, reported in this study, all seaweed species investigated here could be considered appropriate for human consumption and the promotion of good health, particularly the green seaweeds $C$. sertularioides and $R$. riparium and the brown seaweed P. durvillaei. Although the n-3/n-6 ratio for the green seaweed $U$. expansa was $>1$, this value was attributed to the content of fatty acids with 18 carbons and not to the content of HUFAs (fatty acids with $\geq 20$ carbons and $\geq 4$ double bonds). However, this seaweed species should be still considered a good-health promoter because of its unusual fucosterol content and its considerable amount of pigments (i.e., chlorophyll $a$ and $b$, lutein, and $\beta$-carotene), which are compounds with high antioxidant potential. On the other hand, the contents of phytosterols (i.e., brassicasterol, campesterol, stigmasterol, $\beta$-sitosterol, fucosterol, and isofucosterol) in green and brown seaweeds and the high contents of cholesterol+dehydrocholesterol in red seaweeds are good enough to consider these specimens as important health promoters since phytosterols have been demonstrated not only to reduce the content of total cholesterol and LDL-cholesterol in plasma, decreasing cardiovascular diseases, but also to be cytotoxic and pro-apoptotic when phytosterols oxide into oxyphytosterols, constituting alternative approaches for the prevention of carcinogenesis (García-Llatas and Rodríguez-Estrada 2011).

From another point of view, biochemical composition as a source of chemoprotectants has been largely assessed as a tool to explain different bioactivities reported in seaweed species. According to the selected biochemical components (Table 5) and results obtained with the principal component analysis, the biochemical composition was similar in red (G. vermiculophylla and S. filamentosa) and green (C. sertularioides, $R$. riparium, and C. isabelae) seaweeds, but it was particularly different in U. expansa and the brown seaweed (P. durvillaei) (Fig. 1). This common variability and differences in biochemical compositions explain the chemopreventive activities associated with these seaweed species. In a previous study on the same seaweed species as the ones analyzed in the present study, the antioxidant capacity was explained by the content of chlorophylls and flavonoids, but some lipophilic compounds (i.e., fatty acids and phytosterols) were not discarded as effectors of this bioactivity (Osuna-Ruiz et al. 2016). The antioxidant capacity, observed mainly in P. durvillaei and U. expansa, could also be explained by the fucosterol+isofucosterol and fucoxanthin contents, mainly in the brown seaweed. Fucoxanthin is the dominant carotenoid in brown seaweeds, and despite the susceptibility to oxidation on these seaweeds, fucoxanthin is fairly stable in the presence of common antioxidants, such as polyphenols. 1-diphenyl-2-picryl hydrazyl (DPPH) radical a las diferencias en la temporada de recolecta, pero también puede ser causado por las diferencias en los factores ambientales (i.e., temperatura, disponibilidad de nutrientes y salinidad (Guschina y Harwood 2009). Es necesario realizar más investigaciones para establecer las variaciones estacionales y el efecto de los factores ambientales específicos que permitan comparar la composición bioquímica de estas algas marinas entre ambientes de zonas templadas y tropicales.

Debe considerarse la relación entre el valor nutricional de las algas marinas y la composición de ácidos grasos, particularmente aquellos que tienen un número $\geq 20$ carbonos y de la serie $n-3$. Todas las algas marinas presentaron 20:5n-3 (ácido eicosapentaenoico) y 22:6n-3 (ácido docosahexaenoico), los cuales son reconocidos por su alto valor nutricional, incluso las algas marinas verdes $C$. sertularioides y $R$. riparium y la café $P$. durvillaei. El alga marina roja $S$. filamentosa presentó el valor nutricional más alto debido a su mayor contenido de 22:6n-3 (8.9\%), mientras que G. vermiculophylla presentó el menor valor nutricional debido al menor contenido de 20:5n-3 y 22:6n-3. En general, las rodófitas se han identificado por ser una fuente importante de 20:5n-3; sin embargo, el contenido de este AGPI es muy variable (Khotimchenko y Gusarova 2004, Kumari et al. 2010, Imbs et al. 2012, Pereira et al. 2012). La variación estacional de 22:6n-3 en la S. filamentosa de Turquía fue de $0.69 \%$ en la primavera y $3.82 \%$ en el verano (Polat y Ozogul 2013). Kumari et al. (2010) reportaron niveles de $22: 6 \mathrm{n}-3$ de $0.75 \%, 0.96 \%$ y $1.56 \%$ para las algas rojas tropicales Ahnfeltia plicata, Hypnea musciformis y Hypnea esperi, respectivamente, mientras que para 4 especies de algas cafés y 9 verdes reportaron niveles en un intervalo de $0.05-0.78 \%$ y $0.81-5.81 \%$, respectivamente. El contenido de AGPI determinado en el presente estudio para C. sertularioides fue similar a los niveles obtenidos en 3 especies diferentes de Caulerpa reportados previamente (39\% y $29-38 \%$, respectivamente), aunque el contenido de $22: 6 n-3$ fue menor $(0.37 \%$ y $2.8-3.6 \%$, respectivamente), y el $20: 5 n-3$ detectado en C. sertularioides (3.75\%) no fue detectado en las otras 3 especies de Caulerpa (Nagappan y Vairappan 2014).

La Organización Mundial de la Salud recomienda una proporción de n-3/n- $6 \geq 1$, la cual previene trastornos cardiovasculares, enfermedades inflamatorias y cáncer (Simopoulos 2009, Gómez-Candela et al. 2011). Teniendo en cuenta la proporción de n-3/n-6 y el IPI (Tabla 2), el cual indica el grado de insaturación de los ácidos grasos, reportados en este estudio, todas las algas investigadas pueden considerarse apropiadas para el consumo humano y como promotoras de salud, particularmente las algas verdes $C$. sertularioides y $R$. riparium y la café $P$. durvillaei. El alga marina verde $U$. expansa mostró una proporción de n-3/n-6>1, pero esta proporción se debió al contenido de ácidos grasos con 18 carbonos y no al contenido de AGAI (ácidos grasos con $\geq 20$ carbonos y un número $\geq 4$ de dobles enlaces). Sin embargo, esta alga debe ser considerada como promotora de la salud por su inusual contenido de fucosterol y su considerable contenido de pigmentos (i.e., clorofila $a$ y $b$, luteína y $\beta$-caroteno), compuestos con alto 
scavenging activity has been correlated with fucoxanthin content in the 2 brown seaweeds Nizamuddinia zanardinii and Cystoseira indica (Fariman et al. 2016). Fucosterol is the main phytosterol found in Phaeophyceae. It is biosynthesized through the alkylation of 24-methylenecholesterol and is known to possess anticancer and antioxidant activity (Abdul et al. 2016). However, in primitive green algae like Ulva sp., the alkylation of 24-methylenecholesterol leads to the production of a fucosterol isomer called "isofucosterol" (Lopes et al. 2013). On the other hand, fucosterol is the main sterol in brown seaweeds, but fucosterol is also characteristic of some green seaweed species, particularly $U$. expansa, since high proportions of this compound were determined in the present and in previous studies $(78.8 \%$ in the present study, $73.8 \%$ in the study by Ilias et al. 1985); this proportions, however, constrast with the lower value (26\%) (and traces of fucoesterol) found in Ulva lactuca from the Adriatic sea (Kapetanović et al. 2005). In the present research, PUFA content was found in considerable amounts in P. durvillaei but not in U. expansa $(23 \%$ vs $9 \%)$. In addition to the antioxidant effect produced by pigments and sterols in P. durvillaei and $U$. expansa, PUFA contents could exhibit antioxidant capacity. In particular, n-3 series fatty acids showed strong radical scavenging capacity and significant inhibition of reactive oxygen species/reactive nitrogen species (ROS/RNS) production in human endothelial cells, suggesting an effect on inflammation processes that could reduce atherosclerosis and cardiovascular diseases (Richard et al. 2008).

Antioxidants inhibit oxidative reaction cascades, which decrease free-radical concentrations that produce lipid peroxidation and DNA damage or even cell death, and, consequently, induce different chronic diseases and cellular mutations that eventually cause several types of cancer (Duthie et al. 1996). Strong antimutagenic activity against aflatoxin B1 (AFB1) on Salmonella typhimurium TA98 and TA100 tester strains was detected in acetone crude extracts obtained from green (C. sertularioides and $R$. riparium) and red (S. filamentosa) seaweeds (Osuna-Ruiz et al. 2016). Moreover, antiproliferative activity on M12.C3.F6 cells (murine B-cell lymphoma) was also reported for extracts obtained from these seaweed species, showing a dose-response type of relationship, reaching the highest effect $(25 \%$ and $29 \%$ cell proliferation inhibition) at a concentration of $100 \mu \mathrm{g} \cdot \mathrm{mL}^{-1}$ for S. filamentosa and $R$. riparium, respectively; the best inhibition of cancerous cells was observed at the lowest concentrations assayed in C. sertularioides ( $63 \%$ and $28 \%$ for 12.5 and $25 \mu \mathrm{g} \cdot \mathrm{mL}^{-1}$, respectively; Osuna-Ruiz et al. 2016). The highest content of PUFAs and lutein, together with chlorophylls and $\beta$-sitosterol contents, could explain the chemopreventive activity reported for $R$. riparium compared with that of C. sertularioides. This is also consistent with the lowest bioactivity reported for $S$. filamentosa, a seaweed species with the lowest values of PUFA and chlorophyll contents potencial antioxidante. Por otro lado, el contenido de fistoesteroles (i.e., brassicasterol, campesterol, estigmasterol, $\beta$-sitosterol, fucosterol e isofucosterol) en las algas verdes y el alga café y el alto contenido de colesterol+dehidrocolesterol en las algas rojas son buenos argumentos para considerar a estas especies como importantes promotores de la salud, ya que se ha demostrado que los fitoesteroles no solo reducen el colesterol total y de baja densidad (LDL) en el plasma, lo cual disminuye las enfermedades cardiovasculares, sino que también presentan propiedades citotóxicas y pro-apoptosis cuando los fitoesteroles se oxidan en oxifitoesteroles, lo que constituye una aproximación alternativa para la prevención del cáncer (García-Llatas y Rodríguez-Estrada 2011).

Por otra parte, la composición bioquímica como fuente de quimioprotectores ha sido ampliamente estudiada como una herramienta para explicar la diversa bioactividad reportada en las algas marinas. De acuerdo con los componentes bioquímicos seleccionados (Tabla 5) y los resultados obtenidos en el análisis de componentes principales, la composición bioquímica fue similar en las algas rojas (G. vermiculophylla y $S$. filamentosa) y verdes (C. sertularioides, $R$. riparium y C. isabelae), pero particularmente diferente en el alga verde U. expansa y la café (P. durvillaei) (Fig. 1). Esta variabilidad común y las diferencias en la composición bioquímica sirven para explicar la actividad quimiopreventiva asociada a estas especies de algas marinas. Un estudio previo realizado con las mismas especies de algas marinas analizadas en el presente trabajo demostró que la capacidad antioxidante se debió al contenido de clorofilas y flavonoides, sin que se descartara el efecto de los compuestos lipofílicos (i.e., ácidos grasos y fitoesteroles) con bioactividad (Osuna-Ruiz et al. 2016). La capacidad antioxidante, observada principalmente en $P$. durvillaei y $U$. expansa, también puede deberse al contenido de fucosterol+isofucosterol y fucoxantina, principalmente en el alga café. La fucoxantina es el principal carotenoide en las feofitas y, a pesar de la susceptibilidad a la oxidación en estas especies de algas marinas, es muy estable en la presencia de otros antioxidantes, como los polifenoles. La actividad captadora de radicales 1,1 difenil-2-picrilhidrazilo (DPPH) ha sido correlacionada con el contenido de fucoxantina en 2 especies de algas marinas cafés, Nizamuddinia zanardinii y Cystoseira indica (Fariman et al. 2016). El fucosterol es el principal fitoesterol en las feofitas. Este fitoesterol es biosintetizado por la alquilación del 24-methylenecolesterol y es reconocido por su actividad antioxidante y anticancerígena (Abdul et al. 2016). Sin embargo, en las algas marinas verdes primitivas como Ulva sp., la alquilación del 24-methylenecolesterol produce un isómero del fucosterol llamado isofucosterol (Lopes et al. 2013). Por otro lado, el fucosterol es el principal esterol en las algas cafés, pero este compuesto también es característico de algunas algas marinas verdes, particularmente de $U$. expansa, tal y como se comprobó en el presente trabajo (valores de $78.8 \%$ ) y en otros trabajos publicados $(73.8 \%$ reportado en Ilias et al. 1985); estos valores contrastan con los valores bajos de $26 \%$ (y trazas de fucosterol) reportados para 
and no $\beta$-sitosterol experimentally assessed in the present research. High antimutagenic activity on S. typhimurium TA98, TA100, and TA102 has been reported for photosynthetic pigments (Panguestuti and Kim 2011) and for lutein, astaxanthin, and $\beta$-carotene (Bhagavathy et al. 2011). On the other hand, the highest values of $\beta$-sitosterol and fucosterol, without discarding the content of chlorophylls and carotenoids assessed in C. sertularioides, could explain the high inhibition of the proliferation of cancerous cells. Chlorophyll $a, \beta$-carotene, and lutein were identified as the main chemoprotective compounds against mutagen-induced uтu C gene expression in S. typhimurium TA1535/pSK 1002 (Okai et al. 1996). Also, the possible presence of caulerpine, another abundant compound in Caulerpa spp., was not discarded. This non-toxic compound has been characterized in other species (Vidal et al. 1984) and has shown antinociceptive and anti-inflammatory properties in Caulerpa racemosa (de Souza et al. 2009). Moreover, caulerpine and PUFA (18:3n-3, 18:4n-3, and 20:5n-3) contents may explain the potent antimicrobial activity against human food pathogenic bacteria (Escherichia coli, Staphylococcus aureus, Streptococcus sp., and Salmonella sp.), antioxidant activity (nitric oxide production and lactate dehydrogenase), and anti-inflammatory activity against the murine macrophage cell line RAW 264.7 assessed in methanolic extracts of some Caulerpa species (Nagappan and Vairappan, 2014).

In conclusion, the seaweed species studied here differ in biochemical composition and nutritional value with chemopreventive potential activity. In particular, fatty acids, sterols, and pigments in the analyzed tropical seaweeds could be useful as biomarkers to establish specific variations in seaweeds between biogeographic regions (for review see the following references: Gillan et al. 1984, Elenkov et al. 1996, Graeve et al. 2002, Galloway et al. 2012, Kai-Xion et al. 2019). According to the biochemical components that were chosen as biomarkers with known bioactivity, red (G. vermiculophylla and S. filamentosa) and green seaweeds (C. sertularioides, $R$. riparium, and C. isabelae) were similar in composition, but they were particularly different from the green (U. expansa) and the brown (P. durvillaei) seaweeds. The main biochemical compounds that contributed to total variability were $\beta$-sitosterol, PUFAs and HUFAs, 20:4n-6, 20:5n-3, chlorophyll $a$ and $b$, and $\beta$-carotene, and to a lesser extent fucosterol+isofucosterol and 22:6n-3. Differences in the contents of these compounds could explain the chemopreventive activities previously reported for these seaweed species, suggesting neutraceutical applications in the treatment of human diseases. According to the $n-3 / n-6$ ratio, the PUI, and the content of phytosterols, most of the seaweed species studied could be considered promoters of good health and appropriate for human consumption, particularly the green seaweeds $C$. sertularioides and $R$. riparium, and the brown seaweed $P$. durvillaei. Their cultivation in controlled conditions or in integrated multi-trophic culture systems is strongly recommended to evaluate the technical
Ulva lactuca del mar Adriático (Kapetanović et al. 2005). En el presente trabajo, el contenido de AGPI se encontró en cantidades considerables en $P$. durvillaei pero no en $U$. expansa ( $23 \%$ vs $9 \%)$. Además del efecto antioxidante que producen los pigmentos y esteroles de $P$. durvillaei y $U$. expansa, el contenido de AGPI puede tener una capacidad antioxidante. En particular, los ácidos grasos de la serie n-3 han mostrado una fuerte capacidad de reducir radicales y de inhibir la producción de especies reactivas del oxígeno y del nitrógeno (ROS/RNS) en células endoteliales humanas, lo cual sugiere un efecto en el proceso de inflamación que puede reducir la arterioesclerosis y enfermedades cardiovasculares (Richard et al. 2008).

Los antioxidantes inhiben reacciones oxidativas en cascada, lo cual disminuye la concentración de radicales libres que producen la peroxidación de lípidos y el daño al ADN o incluso la muerte celular y, en consecuencia, inducen diferentes enfermedades crónicas y mutaciones celulares que eventualmente pueden causar diversos tipos de cáncer (Duthie et al. 1996). Una fuerte actividad antimutagénica contra la aflatoxina B1 (AFB1) en las cepas TA98 y TA100 de Salmonella typhimurium fue detectada en extractos crudos de acetona obtenidos del alga marina verde $C$. sertularioides y del alga marina roja $S$. filamentosa (Osuna-Ruiz et al. 2016). Además, se ha reportado la actividad antiproliferativa en células M12.C3.F6 (linfoma de células B de murinos) al usar extractos de estas mismas especies de algas y encontraron una relación dosis-respuesta que alcanzó su máximo efecto $(25 \%$ y $29 \%$ de inhibición de proliferación celular) a la concentración de $100 \mu \mathrm{g} \cdot \mathrm{mL}^{-1}$ de S. filamentosa y $R$. riparium, respectivamente; la máxima inhibición de las células cancerosas se observó a las menores concentraciones probadas en C. sertularioides (63\% y $28 \%$ para 12.5 y $25 \mu \mathrm{g} \cdot \mathrm{mL}^{-1}$, respectivamente; Osuna-Ruiz et al. 2016). El mayor contenido de AGPI y luteína, así como de clorofilas y $\beta$-sitosterol, puede explicar la actividad quimiopreventiva reportada para $R$. riparium en comparación con la reportada para C. sertularioides. Esto es consistente con la menor bioactividad reportada para $S$. filamentosa, la especie de alga marina con el menor contenido de AGPI y clorofilas y en la cual no se detectó el $\beta$-sitosterol en la presente investigación. Se ha reportado la alta actividad antimutagénica en las cepas TA98, TA100 y TA102 de S. typhimurium para los pigmentos fotosintéticos (Panguestuti y Kim 2011) y para la luteína, la astaxantina y el $\beta$-caroteno (Bhagavathy et al. 2011). Por otro lado, el alto contenido de $\beta$-sitosterol y fucosterol, sin descartar el contenido de clorofilas y carotenoides determinados en C. sertularioides, puede explicar la alta inhibición de la proliferación de las células cancerosas. La clorofila $a$, el $\beta$-caroteno y la luteína han sido identificados como los principales compuestos quimioprotectores contra la expresión del gen uти C inducido por mutágenos en la cepa TA1535/pSK 1002 de S. typhimurium (Okai et al. 1996). También, no se descarta la posible presencia de la caulerpina, otro compuesto abundante en el género Caulerpa spp. Este compuesto no 
and economic feasibility, allowing for the preservation of the wild beds of these tropical seaweed species.

\section{ACKNOWLEDGMENTS}

This research was supported by the grants PROFAPI 2013/084 to MAHO, PROFAPI 2013/124 to MNS, and PROFAPI 2014/121 and INFR-2012-01-188065 to MMMS. The first author was supported with a scholarship (No. 336726) from the Mexican National Council for Science and Technology. Authors are grateful to Oliva Arjona-López and Celene Navarro-Hurtado for all facilities and technical assistant for the lipid analysis at Laboratory of Lipid Metabolism at CIBNOR, La Paz, Baja California Sur. Special thanks to Guillermo Rodríguez Olibarría (University of Sonora) for his assistance during proximate analysis. We are also grateful to Rosa Stephanie-Navarro Peraza, Francisco FloresCárdenas, and Juan Manuel Flores-Alarcón for their technical assistance during sample collection. A special thanks to the anonymous reviewers for their comments, which improved this manuscript.

\section{REFERENCES}

Angell AR, Mata L, de Nys R, Paul NA. 2016. The protein content of seaweeds: a universal nitrogen-to-protein conversion factor of five. J. Appl. Phycol. 28(1): 511-524. https://doi.org/10.1007/s10811-015-0650-1

Abdul QA, Choi RJ, Jung HA, Choi JS. 2015. Health benefit of fucosterol from marine algae: a review. J. Sci. Food Agric. 96(6): 1856-1866. https://doi.org/10.1002/jsfa.7489

Aguilera-Morales M, Casas-Valdez M, Carrillo-Domínguez S, González-Acosta B, Pérez-Gil F. 2005. Chemical composition and microbiological assays of marine algae Enteromorpha spp. as a potential food source. J. Food Comp. Anal. 18(1): 79-88.

https://doi.org/10.1016/j.jfca.2003.12.012

[AOAC] Association of Official Analytical Chemists International. 2006. Official Methods of Analysis of AOAC International. 18th Ed. Arlington (VA, USA): AOAC International.

Bhagavathy S, Sumathi P, Madhushree M. 2011. Antimutagenic assay of carotenoids from green algae Chlorococcum humicola using Salmonella typhimurium TA98, TA100 and TA102. Asian Pac. J. Trop. Disease 1(4): 308-316. https://doi.org/10.1016/s2222-1808(11)60073-x

Christie H, Norderhaug KM, Frediksen S. 2009. Macrophytes as habitat for fauna. Mar. Ecol. Prog. Ser. 396:221-233. https://doi.org/10.3354/meps08351

De Souza ET, de Lira DP, de Queiroz AC, da Silva DJC, de Aquino AB, Campessato-Mella EA, Lorenzo VP, De Miranda GEC, De Araújo-JúniorJX, De Oliveira-Chaves MC, et al. 2009. The antinociceptive and anti-inflammatory activities of caulerpin, a bisindole alkaloid isolated from seaweeds of the genus Caulerpa. Mar. Drugs 7(4): 689-704. https://doi.org/10.3390/md7040689

Duthie SJ, Ma A, Ross MA, Collins AR. 1996. Antioxidant supplementation decreases oxidative DNA damage in human lymphocytes. Cancer Res. 56(6): 1291-1295.

Elenkov I, Stefanov K, Alexandrova M, Dimitrova-Konaklieva St, Popov S. 1996. Lipid composition of some bulgarian Cladophora tóxico se ha caracterizado en otras especies de este género (Vidal et al. 1984) y ha mostrado tener propiedades antinociceptivas y antiinflamatorias en Caulerpa racemosa (de Souza et al. 2009). Adicionalmente, la caulerpina y el contenido de AGPI (18:3n-3, 18:4n-3 y 20:5n-3) pueden explicar la potente actividad antimicrobiana contra diversas bacterias patógenas encontradas en alimentos para el consumo humano (Escherichia coli, Staphylococcus aureus, Streptococcus sp. y Salmonella sp.), la actividad antioxidante (producción de oxido nítrico y deshidrogenasa láctica) y la actividad antiinflamatoria contra macrófagos de murino de la línea celular RAW 264.7, esto determinado en extractos metanólicos de algunas especies del género Calulerpa (Nagappan y Vairappan 2014).

Se concluye que las especies de algas marinas investigadas en este trabajo difieren en su composición bioquímica y valor nutricional con potencial actividad quimiopreventiva. Particularmente, los ácidos grasos, esteroles y pigmentos determinados en estas especies de algas marinas tropicales pueden ser útiles como biomarcadores para establecer diferencias específicas en las algas entre distintas regiones biogeográficas (para una revisión extensa ver las siguientes referencias: Gillian et al. 1984, Elenkov et al. 1996, Graeve et al. 2002, Galloway et al. 2012, Kai-Xion et al. 2019). De acuerdo con los componentes bioquímicos que fueron seleccionados como biomarcadores y con la bioactividad reconocida, las algas rojas (G. vermiculophylla y S. filamentosa) y verdes (C. sertularioides, $R$. riparium y $C$. isabelae) presentaron composiciones similares, pero fueron particularmente diferentes de las presentadas por el alga verde $U$. expansa y el alga café $P$. durvillaei. Los principales compuestos bioquímicos que contribuyeron a la variabilidad total fueron principalmente el $\beta$-sitosterol, los AGPI, los AGAI, el 20:4n-6, el 20:5n-3, la clorofila $a$ y $b$ y el $\beta$-caroteno, y, en menor grado, el isofucosterol+isofucosterol y el 22:6n-3. Las diferencias en el contenido de estos compuestos podrían explicar la actividad quimiopreventiva reportada previamente para estas especies de algas marinas, lo cual además sugiere aplicaciones nutraceúticas para el tratamiento de enfermedades en humanos. De acuerdo con la proporción de n-3/n-6, el IPI y el contenido de fitoesteroles, la mayoría de las algas marinas investigadas pueden considerarse promotoras de la salud y apropiadas para el consumo humano, particularmente las algas marinas verdes $C$. sertularioides y $R$. riparium y el alga marina café $P$. durvillaei. Se sugiere también iniciar su cultivo en condiciones controladas o en sistemas de cultivo multitróficos para evaluar la viabilidad técnica y económica, lo cual permitirá preservar los lechos silvestres de estas especies de algas marinas tropicales.

\section{Agradecimientos}

Esta investigación fue financiada por los proyectos PROFAPI 2013/084 a MAHO, PROFAPI 2013/124 a MNS, y PROFAPI 2014/121 y INFR-2012-01-188065 a MMMS. El primer autor recibió una beca escolar (No. 336726) del Consejo 
species. 1996. Bot. Mar. 39(1-6): 79-82. https://doi.org/10.1515/botm.1996.39.1-6.79

Fariman GA, Shastan SJ, Zahedi MM. 2016. Seasonal variation of total lipid, fatty acids, fucoxanthin content, and antioxidant properties of two tropical brown algae (Nizamuddinia zanardinii and Cystoseira indica) from Iran. J. Appl. Phycol. 28(2): $1323-1331$. https://doi.org/10.1007/s10811-015-0645-y

Folch J, Lees M, Sloane-Stanley GH. 1957. A simple method for the isolation and purification of total lipids from animal tissues. J. Biol. Chem. 226: 497-509.

Galloway AWE, Britton-Simmons KH, Duggins DO, Gabrielson PW, Brett MT. 2012. Fatty acid signatures differentiate marine macrophytes at ordinal and family ranks. J. Phycol. 48(4): 956-965. https://doi.org/10.1111/j.1529-8817.2012.01173.x

Garbary DJ. 2001. Biogeography of Marine Algae. Encyclopedia of Life Sciences. Heidelberg (Germany): John Wiley \& Sons. https://doi.org/10.1038/npg.els.0000312

García-Llatas G, Rodríguez-Estrada MT. 2011. Current and new insights on phytosterol oxides in plant sterol-enriched food. Chem. Phys. Lipids 164(6): 607-624. https://doi.org/10.1016/j.chemphyslip.2011.06.005

Gillan FT, Hogg RW, Drew EA. 1984. The sterol and fatty acid composition of seven tropical seagrasses from north Queensland, Australia. Phytochemistry 23(12) 2817-2821. https://doi.org/10.1016/0031-9422(84)83021-6

Gómez-Candela C, Bermejo-López LM, Loria-Kohen V. 2011. Importance of a balanced omega 6/omega 3 ratio for the maintenance of health: nutritional recommendations. Nutr. Hosp. 26(2): 323-329.

Graeve M, Kattner G, Wiencke C, Karsten U. 2002. Fatty acid composition of Arctic and Antarctic macroalgae: indicator of phylogenetic and trophic relationships. Mar. Ecol. Prog. Ser. 231: $67-74$. https://doi.org/10.3354/meps231067

Guschina IA, Harwood JL. 2006. Lipids and lipid metabolism in eukaryotic algae. Prog. Lipid Res. 45(2): 160-186. https://doi.org/10.1016/j.plipres.2006.01.001

Hurtado MÁ, Manzano-Sarabia M, Hernández-Garibay E, Pacheco-Ruíz I, Zertuche-González JA. 2011. Latitudinal variations of the yield and quality of agar from Gelidium robustum (Gelidiales, Rhodophyta) from the main commercial harvest beds along the western coast of the Baja California Peninsula, Mexico. J. Appl. Phycol. 23(4): 727-734. https://doi.org/10.1007/s10811-010-9572-0

Imbs AB, Latyshev NA, Svetashev VI, Skriptsova AV, Le TT, Pham MQ, Nguyen VS, Pham LQ. 2012. Distribution of polyunsaturated fatty acids in red algae of the genus Gracilaria, a promising source of prostaglandins. Russ. J. Mar. Biol. 38(4): 339-345. https://doi.org/10.1134/s1063074012040049

Ilias AM, Connor WE, Lin DS, Ahmad MU. 1985. Sterol composition of some seaweeds. Fette, Seifen, Anstrichm. 87(9): 345-346. https://doi.org/10.1002/lipi.19850870905

Jonker D, Van der Hoek GD, Glatz JFC, Homan C, Posthumus MA, Katan MB. 1985. Combined determination of free, esterified and glycosilated plant sterols in foods. Nutr. Rep. Int. 32(4): 943-952.

Kai-Xiong Y, Ting-Ting F, Lawrence JK, Bing-Nan H. 2019. A review of pigments derived from marine natural products. Israel J. Chem. 59(5): 327-338. https://doi.org/10.1002/ijch.201800154
Nacional de Ciencia y Tecnología (México). Los autores agradecemos a Oliva Arjona-López y Celene Navarro-Hurtado su apoyo con instalaciones y su asistencia técnica para el análisis de lípidos en el Laboratorio de Metabolismo de Lípidos del CIBNOR, La Paz, Baja California Sur. Un agradecimiento especial a Guillermo Rodríguez Olibarría (Universidad de Sonora) por su asistencia en el análisis proximal. También agradecemos el apoyo técnico brindado por Rosa Stephanie Navarro-Peraza, Francisco Flores-Cárdenas y Juan Manuel Flores-Alarcón durante la recolección de las muestras de las algas marinas. Agradecemos a los revisores anónimos sus comentarios para mejorar este manuscrito.

Kapetanović R, Sladić DM, Popov S, Zlatović MV, Kljajić Z, Gašić MJ. 2005. Sterol composition of the Adriatic Sea algae Ulva lactuca, Codium dichotomum, Cystoseira adriatica, and Fucus virsoides. J. Serbian Chem. Soc. 70(12): 1395-1400. https://doi.org/10.2298/jsc0512395k

Khotimchenko SV, Gusarova IS. 2004. Red algae of Peter the Great Bay as a source of arachidonic and eicosapentaenoic acids. Russ. J. Mar. Biol. 30(3): 183-187. https://doi.org/10.1023/b:rumb.0000033953.67105.6b

Kumari P, Kumar M, Gupta V, Reddy CRK, Jha B. 2010. Tropical marine macroalgae as potential sources of nutritionally important PUFAs. Food Chem. 120(3): 749-757. https://doi.org/10.1016/j.foodchem.2009.11.006

Lobban CS, Harrison PJ, 1994. Seaweed Ecology and Physiology. Cambridge (United Kingdom): Cambridge University Press; $367 \mathrm{pp}$.

Lopes G, Sousa C, Valentão P, Andrade PB. 2013. Sterols in algae and health. In: Hernández-Ledesma B, Herrero M (eds.), Bioactive Compounds from Marine Foods: Plant and Animal Sources: [Place Unknown]: John Wiley \& Son; p. 173-191. https://doi.org/10.1002/9781118412893.ch9

Lourenço SO, Barbarino E, De-Paula JC, da S Pereira LO, LanferMarquez UM. 2002. Amino acid composition, protein content and calculation of nitrogen-to-protein conversion factors for 19 tropical seaweeds. Phycol. Res. 50(3): 233-241. https://doi.org/10.1046/j.1440-1835.2002.00278.x

Mann KH. 1973. Seaweeds: Their productivity and strategy for growth. Science 182(4116): 975-81. https://doi.org/10.1126/science.182.4116.975

Nagappan T, Vairappan CS. 2014. Nutritional and bioactive properties of the three edible species of green algae, genus Caulerpa (Caulerpaceae). J. Appl. Phycol. 26(2): 10191027. https://doi.org/10.1007/s10811-013-0147-8

Nelson MM, Phleger CF, Nichols PD. 2002. Seasonal lipid composition in macroalgae of the northeastern Pacific Ocean. Bot. Mar. 45(1): 58-65. https://doi.org/10.1515/bot.2002.007

Okai Y, Higashi-Okai K, Yano Y, Otani S. 1996. Identification of antimutagenic substances in an extract of edible red alga, Porphyra tenera (Asadusa-nori). Cancer Lett. 100(1-2): 235-240. https://doi.org/10.1016/0304-3835(95)04101-x

Osuna-Ruiz I, López-Saiz CM, Burgos-Hernández A, Velázquez C, Nieves-Soto M, Hurtado-Oliva MA. 2016. Antioxidant, antimutagenic and antiproliferative activities in selected seaweed species from Sinaloa, Mexico. Pharm. Biol. 54(10): 2196-2210.

https://doi.org/10.3109/13880209.2016.1150305 
Palacios E, Racotta IS, Arjona O, Marty Y, Le Coz JR, Moal J, Samain JF. 2007. Lipid composition of the pacific lion-paw scallop, Nodipecten subnodosus, in relation to gametogenesis: 2. Lipid classes and sterols. Aquaculture 266(1-4): 266-273. https://doi.org/10.1016/j.aquaculture.2007.02.030

Pangestuti R, Kim SK. 2011. Biological activities and health benefit effects of natural pigments derived from marine algae. J. Funct. Foods 3(4): 255-266. https://doi.org/10.1016/j.jff.2011.07.001

Paul-Chávez L, Riosmena-Rodriguez R. 2000. Floristic and biogeographical trends in seaweed assemblages from a subtropical insular island complex in the Gulf of California. Pacific Science 54(2): 137-147.

Peña-Rodríguez A, Mawhinney TP, Ricque-Marie D, Cruz-Suárez LE. 2011. Chemical composition of cultivated seaweed Ulva clathrata (Roth) C. Agardh. Food Chem. 129(2): 491-498. https://doi.org/10.1016/j.foodchem.2011.04.104

Peraza-Yee MM. 2014. Caracterización química de macroalgas Ulva expansa, Ulva lobata, Colpomenia tuberculata, Padina durvillei y Gracilaria vermiculophylla recolectadas en el litoral de Mazatlán (Bahía y Estero de Urías) [MSc thesis]. [Mazatlan (Sinaloa, Mexico)]: Universidad Nacional Autónoma de México; $110 \mathrm{pp}$.

Pereira H, Barreira L, Figueiredo F, Custódio L, Vizetto-Duarte C, Polo C, Rešek E, Engelen A, Varela J. 2012. Polyunsaturated fatty acids of marine macroalgae: Potential for nutritional and pharmaceutical applications. Mar. Drugs 10(9): 1920-1935. https://doi.org/10.3390/md10091920

Plaza M, Cifuentes A, Ibáñez E. 2008. In the search of new functional ingredients from algae. Trends Food Sci. Technol. 19(1): 31-39.

https://doi.org/10.1016/j.tifs.2007.07.012

Plaza M, Santoyo S, Jaime L, García-Blairsy Reina G, Herrero M, Señoráns FJ, Ibáñez E. 2010. Screening for bioactive compounds from algae. J. Pharmaceut. Biomed. Anal. 51(2) 450-455. https://doi.org/10.1016/j.jpba.2009.03.016

Polat S, Ozogul Y. 2013. Seasonal proximate and fatty acid variations of some seaweeds from the northeastern Mediterranean coast. Oceanologia 55(2): 375-391. https://doi.org/10.5697/oc.55-2.375

Quintana-López A, Hurtado-Oliva MA, Manzano-Sarabia M, López-Peraza DJ, Hernández C, García A, Palacios E. 2019. Effect of rearing conditions on astaxanthin accumulation in the white shrimp Penaeus vannamei (Boone, 1931). Lat. Amer. J. Aqua. Res. 47(2): 303-309. https://doi.org/10.3856/vol47-issue2-fulltext-10

Richard D, Kefi K, Barbe U, Bausero P, Visioli F. 2008. Polyunsaturated fatty acids as antioxidants. Pharmacol. Res. 57(6): 451-455. https://doi.org/10.1016/j.phrs.2008.05.002

Robledo D, Freile-Pelegrín Y. 1997. Chemical and mineral composition of six potentially edible seaweed species of
Yucatán. Bot. Mar. 40(4): 301-306.

https://doi.org/10.1515/botm.1997.40.1-6.301

Serviere-Zaragoza E, Hurtado MA, Manzano-Sarabia M, Mazariegos-Villarreal A, Reza M, Arjona O, Palacios E. 2015. Seasonal and interannual variation of fatty acids in macrophytes from the Pacific coast of Baja California Peninsula (Mexico). J. Appl. Phycol. 27(3): 1297-1306. https://doi.org/10.1007/s10811-014-0415-2

Serviere-Zaragoza E, Gómez-López D, Ponce-Diaz G. 2002. Gross chemical composition of three common macroalgae and a seagrass on tha Pacific coast of Baja California Mexico = Composición química gruesa de tres macroalgas y un pasto marino en la costa del Pacífico de Baja California, México. Hidrobiológica 12(2): 113-118.

Silva PC. 1992. Geographic patterns of diversity in benthic marine algae. Pacific Science 46(4): 429-437.

Simopoulos AP. 2009. Omega-6/Omega-3 essential fatty acids: biological effects. World Rev. Nutr. Diet. 99: 1-16. https://doi.org/10.1159/000192755

Stevens GC. 1989. The latitudinal gradient in geographical range: How so many species coexist in the tropics. Am. Nat. 133(2): 240-256. https://doi.org/10.1086/284913

Stevens GC. 1992. The elevational gradient in altitudinal range: an extension of Rapoport's latitudinal rule to altitude. Am. Nat. 140(6): 893-911. https://doi.org/10.1086/285447

Van den Hoek C. 1984. World-wide latitudinal and longitudinal seaweed distribution patterns and their possible causes, as illustrated by the distribution of Rhodophytan genera. Helgoland. Meer. 38(2): 227-257. https://doi.org/10.1007/bf01997483

Vidal JP, Laurent D, Kabore SA, Rechencq E, Boucard M, Girard JP, Escale R, Rossi JC. 1984. Caulerpin, Caulerpicin, Caulerpa scalpelliformis: Comparative acute toxicity study. Bot. Mar. 27(12): 533-537. https://doi.org/10.1515/botm.1984.27.12.533

Xu XQ, Tran VH, Kraft G, Beardall J. 1998. Fatty acids of six Codium species from southeast Australia. Phytochemistry 48(8): 1335-1339. https://doi.org/10.1016/S0031-9422(98)00115-0

Zapata M, Rodríguez F, Garrido JL. 2000. Separation of chlorophylls and carotenoids from marine phytoplankton: a new HPLC method using a reversed phase $\mathrm{C}_{8}$ column and pyridine-containing mobile phases. Mar. Ecol. Prog. Ser. 195: $29-45$. https://doi.org/10.3354/meps195029

Zar JH. 1999. Biostatistical Analysis. 4th Ed. Upper Saddle River (NJ): Prentice-Hall; 663 pp.

Received February 2019, 